Atmos. Chem. Phys., 11, 13339-13357, 2011

www.atmos-chem-phys.net/11/13339/2011/

doi:10.5194/acp-11-13339-2011

(C) Author(s) 2011. CC Attribution 3.0 License.

\title{
Source apportionment of the summer time carbonaceous aerosol at Nordic rural background sites
}

\author{
K. E. Yttri ${ }^{1}$, D. Simpson ${ }^{2,3}$, J. K. Nøjgaard ${ }^{4}$, K. Kristensen ${ }^{5}$, J. Genberg ${ }^{6}$, K. Stenström ${ }^{6}$, E. Swietlicki ${ }^{6}$, R. Hillamo ${ }^{7}$, \\ M. Aurela ${ }^{7}$, H. Bauer ${ }^{8}$, J. H. Offenberg ${ }^{9}$, M. Jaoui ${ }^{10}$, C. Dye ${ }^{1}$, S. Eckhardt ${ }^{1}$, J. F. Burkhart ${ }^{1}$, A. Stohl ${ }^{1}$, and \\ M. Glasius ${ }^{5}$ \\ ${ }^{1}$ NILU - Norwegian Institute for Air Research, Kjeller, Norway \\ ${ }^{2}$ EMEP MSC-W, Norwegian Meteorological Institute, Oslo, Norway \\ ${ }^{3}$ Department Earth and Space Sciences, Chalmers University of Technology, Gothenburg, Sweden \\ ${ }^{4}$ Department of Environmental Science, Aarhus University, Roskilde, Denmark \\ ${ }^{5}$ Department of Chemistry, Aarhus University, Aarhus C, Denmark \\ ${ }^{6}$ Lund University, Department of Physics, Division of Nuclear Physics, Lund, Sweden \\ ${ }^{7}$ Finnish Meteorological Institute, Research and Development, Helsinki, Finland \\ ${ }^{8}$ Vienna University of Technology, Vienna, Austria \\ ${ }^{9}$ US Environmental Protection Agency, Research Triangle Park, North Carolina, USA \\ ${ }^{10}$ Alion Science and Technology, Research Triangle Park, North Carolina, USA
}

Received: 8 April 2011 - Published in Atmos. Chem. Phys. Discuss.: 6 June 2011

Revised: 2 December 2011 - Accepted: 6 December 2011 - Published: 22 December 2011

\begin{abstract}
In the present study, natural and anthropogenic sources of particulate organic carbon $\left(\mathrm{OC}_{\mathrm{p}}\right)$ and elemental carbon (EC) have been quantified based on weekly filter samples of $\mathrm{PM}_{10}$ (particles with aerodynamic diameter $<10 \mu \mathrm{m})$ collected at four Nordic rural background sites [Birkenes (Norway), Hyytiälä (Finland), Vavihill (Sweden), Lille Valby, (Denmark)] during late summer (5 August-2 September 2009). Levels of source specific tracers, i.e. cellulose, levoglucosan, mannitol and the ${ }^{14} \mathrm{C} /{ }^{12} \mathrm{C}$ ratio of total carbon (TC), have been used as input for source apportionment of the carbonaceous aerosol, whereas Latin Hypercube Sampling (LHS) was used to statistically treat the multitude of possible combinations resulting from this approach.

The carbonaceous aerosol (here: $\mathrm{TC}_{\mathrm{p}}$; i.e. particulate $\mathrm{TC}$ ) was totally dominated by natural sources $(69-86 \%)$, with biogenic secondary organic aerosol (BSOA) being the single most important source (48-57\%). Interestingly, primary
\end{abstract}

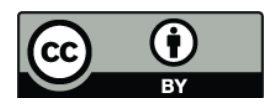

Correspondence to: K. E. Yttri (key@nilu.no) biological aerosol particles (PBAP) were the second most important source (20-32\%). The anthropogenic contribution was mainly attributed to fossil fuel sources $\left(\mathrm{OC}_{\mathrm{ff}}\right.$ and $\left.\mathrm{EC}_{\mathrm{ff}}\right)$ (10-24\%), whereas no more than 3-7\% was explained by combustion of biomass $\left(\mathrm{OC}_{\mathrm{bb}}\right.$ and $\left.\mathrm{EC}_{\mathrm{bb}}\right)$ in this late summer campaign i.e. emissions from residential wood burning and/or wild/agricultural fires. Fossil fuel sources totally dominated the ambient EC loading, which accounted for $4-12 \%$ of $\mathrm{TC}_{\mathrm{p}}$, whereas $<1.5 \%$ of $\mathrm{EC}$ was attributed to combustion of biomass. The carbonaceous aerosol source apportionment showed only minor variation between the four selected sites. However, Hyytiälä and Birkenes showed greater resemblance to each other, as did Lille Valby and Vavihill, the two latter being somewhat more influenced by anthropogenic sources.

Ambient levels of organosulphates and nitrooxy-organosulphates in the Nordic rural background environment are reported for the first time in the present study. The most abundant organosulphate compounds were an organosulphate of isoprene and nitrooxy-organosulphates of $\alpha$ - and $\beta$-pinene and limonene. 


\section{Introduction}

The ambient air carbonaceous aerosol (here: particulate carbonaceous matter $(\mathrm{PCM})=$ organic matter $(\mathrm{OM})+$ elemental carbon (EC)) is found to be abundant in the European rural background environment, accounting for 10-40\% (mean $30 \%$ ) of $\mathrm{PM}_{10}$ (Yttri et al., 2007a; Putaud et al., 2004). The carbonaceous aerosol is believed to have an important impact on the global climate (e.g. Kanakidou et al., 2005), as well as causing adverse affects on human health (e.g. Metzger et al., 2004; Bell et al., 2009). Both anthropogenic (e.g. fossil fuel combustion) and biogenic sources (mainly biogenic secondary organic aerosol, BSOA, and primary biological aerosol particles, PBAP, such as degraded plant material and fungal spores) contribute to the carbonaceous aerosol loading, and its complexity in terms of composition, formation mechanisms and sources has been the topic of a number of recent studies (e.g. Donahue et al., 2005, 2009; Kanakidou et al., 2005; Hallquist et al., 2009). The carbonaceous aerosol can be either primary, i.e. from direct emissions, or secondary, i.e. low volatility products following from reactions between volatile organic compounds (VOC) or oxidants in the atmosphere. In particular, the reactions of unsaturated biogenic VOCs with ozone $\left(\mathrm{O}_{3}\right)$, nitrate radicals $\left(\mathrm{NO}_{3}\right)$ and hydroxyl radicals $(\mathrm{OH})$ have been extensively studied to evaluate the chemical speciation and aerosol yield (Hallquist et al., 2009; Hoffmann et al., 1997; Kavouras and Stephanou, 2002). The products range from volatile to non-volatile species capable of forming new particles, and include a variety of oxygenated carbon compounds (Atkinson and Arey, 2003).

During the last few years a number of studies have become available which point towards natural sources as particularly important contributors to the carbonaceous aerosol loading in Europe, during summertime, including both the rural and the urban environment (e.g. Gelenscer et al., 2007; Szidat et al., 2006, 2009; Yttri et al., 2011). Common for these studies is that they have used ${ }^{14} \mathrm{C}$ analysis along with source specific organic tracers to distinguish between and quantify carbonaceous aerosol from anthropogenic and natural sources. Carbon from fossil fuel sources is devoid of ${ }^{14} \mathrm{C}$ due to radioactive decay, while carbon in most living materials has the same ${ }^{14} \mathrm{C} /{ }^{12} \mathrm{C}$ ratios similar to that of atmospheric carbon dioxide. The organic tracers are used to further distinguish between the sources emitting contemporary carbon; e.g. the biomass burning tracer levoglucosan is used to apportion carbonaceous aerosol from biomass burning.

The carbonaceous aerosol observed in the Nordic countries (represented in the current study by Denmark, Finland, Norway and Sweden) are likely substantially influenced by natural sources, particularly in summer. The northern part of the study area in the present study is located within the Boreal region where large forested areas emit PBAP and biogenic VOCs forming secondary organic aerosol (SOA) (Anderson-Sköld and Simpson, 2001; Tunved et al., 2006; Saarikoski et al., 2008; Yttri et al., 2007a, b, 2011). Particle-phase oxidation products of biogenic VOCs have been used as chemical markers to evaluate the contribution from SOA to the carbonaceous aerosol (Kourtchev et al., 2008a; Kleindienst et al., 2007). Such oxidation products have been identified in laboratory studies involving isoprene, monoterpenes and sesquiterpenes (Hallquist et al., 2009 and references therein). A widely used marker is cis-pinic acid, which is formed during oxidation of the abundant monoterpenes $\alpha$-pinene and $\beta$-pinene by $\mathrm{O}_{3}$ and $\mathrm{OH}$ (Christoffersen et al., 1997; Larsen et al., 2001; Yu et al., 1999). Cis-pinic acid has been detected in a number of locations, and recently in Hyytiälä, with concentrations ranging from $2-30 \mathrm{ng} \mathrm{m}^{-3}$ (Kourtchev et al., 2008b). Organosulphates and nitrooxy organosulphates of isoprene and monoterpenes were recently identified as products of acid-catalyzed uptake of their VOC precursors in the aerosol phase (e.g. Surratt et al., 2007, 2010; Iinuma et al., 2007). Organosulphates and nitrooxy organosulfates are formed by processes involving both biogenic and anthropogenic emissions, and can thus be regarded as tracers of ageing of aerosols in mixed air masses.

Cellulose is used as a quantitative tracer of plant debris (Puxbaum and Tenze Kunit, 2003; Gelencsér et al., 2007; Sánchez-Ochoa et al., 2007), whereas mannitol and arabitol are tracers used to account for the contribution of Asco- and Basidio-mycetes fungal spores (Bauer et al., 2008). Plant debris and fungal spores are likely the major contributors to the atmospheric mass concentration of PBAP (Bauer et al., 2002, 2008; Puxbaum and Tenze-Kunit, 2003; Yttri et al., 2011) and its abundance in the Nordic rural background environment has been demonstrated by Yttri et al. (2011).

Residential wood burning is common in the Nordic countries, particularly during the cold season, and contributes to the carbonaceous aerosol loading both in the urban and the rural background environment (Yttri et al., 2005, 2009; Glasius et al., 2006, 2008; Krecl et al., 2007, Saarikoski et al., 2008). Levoglucosan is a thermal degradation product of cellulose emitted in high concentrations during combustion of biomass and which is widely used as a tracer for carbonaceous aerosol emissions, including emissions both from residential heating and wild/agricultural fires (Simoneit et al., 1999; Puxbaum et al., 2007). Recent studies have indicated that levoglucosan can be prone to degradation in the atmosphere and particularly by $\mathrm{OH}$ (Hoffmann et al., 2010; Hennigan et al., 2010). Thus, its stability during long-range transport and during summer in particular, can be questioned.

It is well documented that the Nordic countries are subject to long-range transport (LRT) of particulate matter air pollution, in particular from the more densely populated areas of continental Europe, but also as a results of distant wild and agricultural fires (Stohl et al., 2007; Yttri et al., 2007a; Saarikoski et al., 2008). During the EMEP (European 
Monitoring and Evaluation Programme) EC/OC campaign (2002-2003), organic matter (OM) accounted for 36-38\% of $\mathrm{PM}_{10}$ at Nordic rural background sites in summer, whereas the corresponding range for EC was 1.8-2.9\%. In contrast to continental European rural background sites, the Nordic ones experienced $30 \%$ higher levels of organic carbon (OC) in summer compared to winter (Yttri et al., 2007a). This distinct pattern likely reflects a seasonal increase in (B)SOA and PBAP, as well as low influence of anthropogenic sources. This is in accordance with observations of high aerosol loadings over boreal forests, which can be explained by the relationship between monoterpene emissions and gas to particle conversion following atmospheric oxidation (Tunved et al., 2006). Saarikoski et al. (2008) nicely demonstrated that $17-29 \%$ of OC in the Helsinki urban background environment was attributed to LRT, and that the relative contribution of LRT peaked in spring. The LRT OC was found to be a mixture of components originating from both primary and secondary sources.

The objective of the SONORA (Secondary Organic aerosol in the NOrdic RurAl Environment) study was to provide quantitative estimates of the most abundant sources contributing to the carbonaceous aerosol in the Nordic rural background environment in summer. The source apportionment of the carbonaceous aerosol was based on the content of selected source specific organic tracers, EC, $\mathrm{OC}$, and the fraction of modern carbon $\left(\mathrm{F}^{14} \mathrm{C}\right)$ of $\mathrm{TC}$ in particle filter samples collected at four sites in four different countries. The dataset benefits from the use of centralized laboratories for the various species analyzed and that sampling artifacts have been accounted for. By using Latin Hypercube Sampling for statistical treatment (similar to Gelenscer et al., 2007; Yttri et al., 2011), seven subcategories/sources of the carbonaceous aerosol have been apportioned. In the current paper we present the main findings from the SONORA study.

\section{Experimental}

\subsection{Site description and measurement period}

Aerosol filter samples were collected at four Nordic rural background sites (Table 1, Fig. 1), all representative for various environmental types encountered in Northern Europe. The samples were collected during the period 5 August to 9 September 2009.

The Birkenes atmospheric research station $\left(58^{\circ} 23^{\prime} \mathrm{N}\right.$, $8^{\circ} 15^{\prime} \mathrm{E}, 190 \mathrm{~m}$ a.s.l.) is a joint supersite for EMEP and GAW (Global Atmospheric Watch) and is situated approximately $20 \mathrm{~km}$ from the Skagerrak coast in southern Norway. The station is located in the boreal forest with mixed conifer and deciduous trees accounting for $65 \%$ of the land use in the vicinity of the site; the remaining $35 \%$ is attributed to meadow $(10 \%)$, low intensity agricultural areas $(10 \%)$, and freshwater lakes $(15 \%)$. The nearest local emission source is the city of Kristiansand (65000 inhabitants), located $25 \mathrm{~km}$ south/south-west of the station, which is known to have minor or even negligible influence on the air quality at the site.

The SMEAR-II (Station for Measuring Forest EcosystemAtmosphere Relations) station Hyytiälä $\left(61^{\circ} 51^{\prime} \mathrm{N}, 24^{\circ} 17^{\prime} \mathrm{E}\right.$, $181 \mathrm{~m}$ a.s.l.) is located in a rather homogeneous Scots pine (Pinus sylvestris) stand on a flat terrain at Hyytiälä Forestry Field Station of the University of Helsinki, $220 \mathrm{~km}$ northwest from Helsinki. The site represents the rural background area of Southern Finland. Occasionally measurements can be affected by the station buildings ( $0.5 \mathrm{~km}$ away) and the city of Tampere (population of $200000,60 \mathrm{~km}$ away) both located west to south-west of the site.

Lille Valby $\left(55^{\circ} 41^{\prime} \mathrm{N}, 12^{\circ} 07^{\prime} \mathrm{E}, 12 \mathrm{~m}\right.$ a.s.l.) is a semi-rural monitoring station in the Sjaelland region of Denmark, which is situated in the boreal zone. The surronding area is characterized by agricultural land, small villages and the Roskilde Fjord ( $1 \mathrm{~km}$ west of the monitoring site). The station is located $30 \mathrm{~km}$ to the west of Copenhagen $(1.2$ million inhabitants), and $7 \mathrm{~km}$ North-East of central Roskilde (46 000 inhabitants). The nearest road (A6 with about 15800 vehicles day ${ }^{-1}$ ) is located about $0.8 \mathrm{~km}$ west of the station.

Vavihill is a EUSAAR (European Supersites for Atmospheric Aerosol Research) and EMEP site situated in Southern Sweden $\left(56^{\circ} 01^{\prime} \mathrm{N}, 13^{\circ} 09^{\prime} \mathrm{E}, 172 \mathrm{~m}\right.$ a.s.l. $)$. The surrounding area is dominated by grassland (49\%) deciduous trees $(40 \%)$ and farmland $(10 \%)$. The site is situated $25-45 \mathrm{~km}$ north-east to east of the densely populated areas of Greater Malmö (630 000 inhabitants), Copenhagen and Helsingborg (100000 inhabitants) and continental air masses passing over these areas are typically more polluted than air masses originating from other directions.

\subsection{Aerosol sampling}

Ambient aerosol filter samples were obtained using the Klein-filtergerät low volume sampler equipped with a $\mathrm{PM}_{10}$ inlet, collecting aerosols on prefired $\left(850^{\circ} \mathrm{C} ; 3 \mathrm{~h}\right)$ quartz fibre filters (Whatman QMA; $47 \mathrm{~mm}$ in diameter, batch number 11415138). The filter samples were collected according to the Quartz fibre filter behind Quartz fibre filter (QBQ) approach to provide a quantitative estimate of the positive sampling artefact of organic carbon (OC). The instruments were operated at a flow rate of $381 \mathrm{~min}^{-1}$, corresponding to a filter face velocity ranging between 50 and $54 \mathrm{~cm} \mathrm{~s}^{-1}$ (see Table 1), depending on the actual exposed filter area. The sampling time was 1 week, and a total of 4 samples were collected at each site. The sampling inlets were installed approximately $4 \mathrm{~m}$ above ground level. Post exposure the filter samples were placed in petrislides, and stored in a freezer at $-18^{\circ} \mathrm{C}$ in order to prevent any form of degradation or evaporation of the analytes. 
Table 1. Location of the four Nordic rural background sites participating in the SONORA sampling campaign and the duration of the sampling period. The inlet cut-off size, volumetric flow rate, and filter face velocity of the aerosol samplers applied is also provided.

\begin{tabular}{lrrrrrr}
\hline $\begin{array}{l}\text { Sampling } \\
\text { site }\end{array}$ & Location & $\begin{array}{r}\text { Height } \\
(\mathrm{m} \mathrm{a.s.1.)}\end{array}$ & Sampling period & $\begin{array}{r}\text { Cut-off } \\
\text { size }\end{array}$ & $\begin{array}{r}\text { Flow rate } \\
\left(1 \mathrm{~min}^{-1}\right)\end{array}$ & $\begin{array}{r}\text { Filter face velocity } \\
\left(\mathrm{cm} \mathrm{s}^{-1}\right)\end{array}$ \\
\hline Birkenes (Norway) & $58^{\circ} 23^{\prime} \mathrm{N}, 8^{\circ} 15^{\prime} \mathrm{E}$ & 190 & $05.08 .2009-02.09 .2009$ & $\mathrm{PM}_{10}$ & 38 & 58 \\
Hyytiälä (Finland) & $61^{\circ} 51^{\prime} \mathrm{N}, 24^{\circ} 17^{\prime} \mathrm{E}$ & 181 & $12.08 .2009-09.09 .2009$ & $\mathrm{PM}_{10}$ & 38 & 38 \\
Lille Valby (Denmark) & $55^{\circ} 41^{\prime} \mathrm{N}, 12^{\circ} 08^{\prime} \mathrm{E}$ & 10 & $05.08 .2009-02.09 .2009$ & $\mathrm{PM}_{10}$ & 30 \\
Vavihill (Sweden) & $56^{\circ} 01^{\prime} \mathrm{N}, 13^{\circ} 09^{\prime} \mathrm{E}$ & 172 & $05.08 .2009-02.09 .2009$ & $\mathrm{PM}_{10}$ & 38 \\
\hline
\end{tabular}

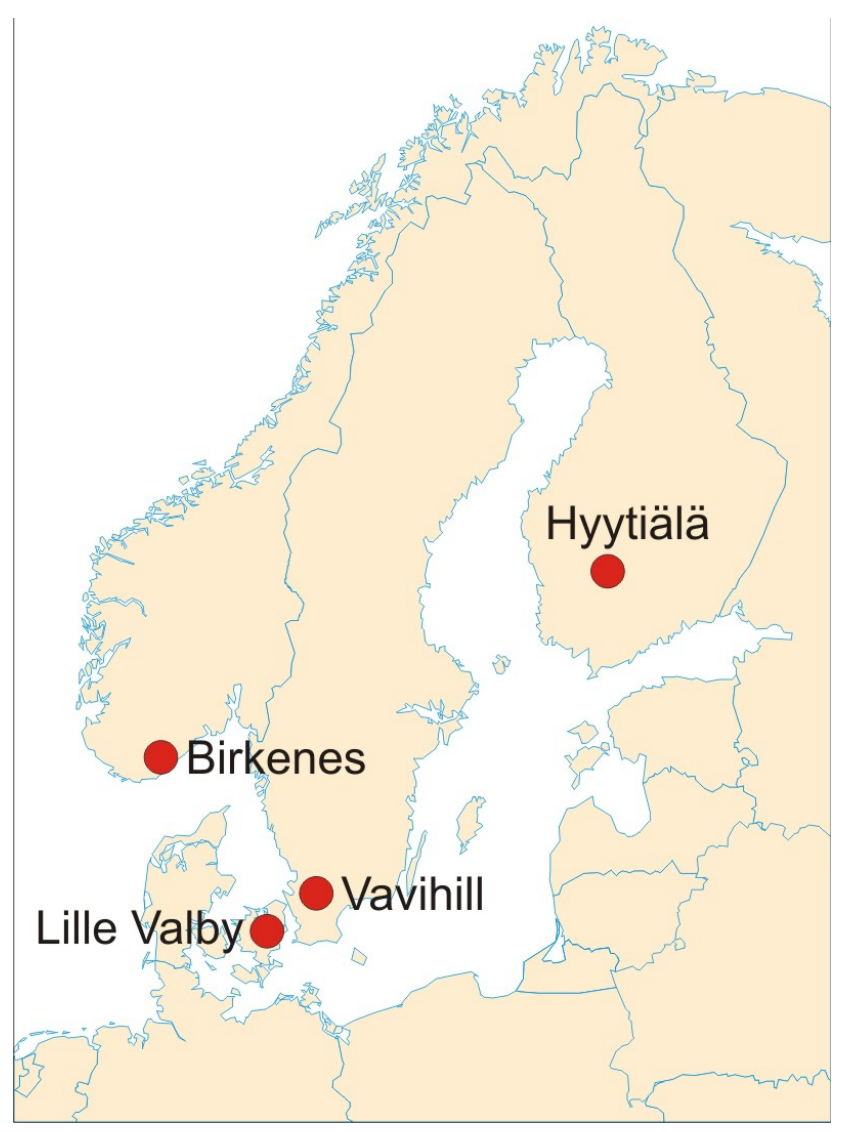

Fig. 1. Map of Northern Europe including the location of the sampling sites Birkenes (Norway), Hyytiälä (Finland), Lille Valby (Denmark) and Vavihill (Sweden) in the Nordic countries.

\subsection{Thermal-optical analysis}

Three of the four partners used the thermal-optical instrument from Sunset laboratories Inc. to quantify the samples content of total carbon (TC), elemental carbon (EC), and organic carbon (OC), whereas the forth partner used the OC/EC Thermal Optical Carbon Analyzer from DRI (Desert Research Institute). Both instrument types corrected for charring of OC during analysis using transmission and operated according to the EUSAAR 2 thermal program
(Cavalli et al., 2010). The analytical detection limit of the $\mathrm{EC} / \mathrm{OC}$ analyses is $0.2 \mu \mathrm{g} \mathrm{Cm}^{-2}$.

\section{$2.4{ }^{14} \mathrm{C}$-analysis}

80-200 $\mu \mathrm{g}$ of carbon was extracted from each filter prior to ${ }^{14} \mathrm{C}$ analysis, corresponding to a filter area of $1-4 \mathrm{~cm}^{2}$ for front filters and $11 \mathrm{~cm}^{2}$ for backup filters. In the first step of the analysis, the sample was combusted in the presence of precleaned $\mathrm{CuO}$ needles $(1 \mathrm{~g}$; Merck pro analysis, $0.65 \times 6 \mathrm{~mm}$ ) in a vacuum system to yield $\mathrm{CO}_{2}$ (Genberg et al., 2010). Solid graphite targets were then produced by reducing the formed $\mathrm{CO}_{2}$ using $\mathrm{H}_{2}$ and a heated $\left(600^{\circ} \mathrm{C}\right)$ metal catalyst $(1 \mathrm{mg} \mathrm{Fe}$, Merck, pro analysis, reduced, diameter $10 \mu \mathrm{m})$. $\mathrm{Mg}\left(\mathrm{ClO}_{4}\right)_{2}$ (Merck, diameter 1-4 mm) was used as a drying agent. The time for complete reduction of each sample was less than $4 \mathrm{~h}$. After complete graphitization, the carbon and iron catalyst were pressed into an aluminum sample holder. The sample holders containing the carbon from the aerosol samples were placed on a 40 position sample wheel together with graphitized standards (4 OxI as primary standard; 2 IAEA-C6 and 2 IAEA-C7 as secondary standards) and blanks (made from bottled, commercial fossil $\mathrm{CO}_{2}$ which was combusted and graphitized as the rest of the samples and standards). The ${ }^{14} \mathrm{C}$ analysis was performed using the single stage accelerator mass spectrometry (SSAMS) facility at Lund University (Skog, 2007; Skog et al., 2010).

\subsection{Measurement of levoglucosan, mannosan and galactosan}

Quantification of the monosaccharide anhydrides (MA) levoglucosan, mannosan and galactosan was performed according to the method by Dye and Yttri (2005), and is only briefly described here. One punch $\left(1.5 \mathrm{~cm}^{2}\right)$ of the quartz fibre filter was soaked in tetrahydrofuran $(2 \mathrm{ml})$ and subjected to ultrasonic agitation $(30 \mathrm{~min})$. The filter extract was filtered through a syringe filter $(0.45 \mu \mathrm{m})$ to remove $\mathrm{PM}$ and filter parts. Each filter was extracted twice. The extracted volumes were pooled and evaporated to a total volume of $1 \mathrm{ml}$ in an $\mathrm{N}_{2}$ atmosphere. Before analysis the sample solvent elution strength was adapted to the mobile 
phase by adding Milli-Q water $(0.8 \mathrm{ml})$. The concentrations of MAs were determined using High Performance Liquid Chromatography (HPLC) (Agilent model 1100) in combination with HRMS-TOF (High Resolution Mass spectrometry Time-of-Flight) (Micromass model LCT) operated in the negative electrospray mode. The compound separation was performed with two series-connected reversed-phase C18 columns (Atlantis dC18, Waters). Levoglucosan, mannosan, and galactosan were identified on the basis of retention time and mass spectra of authentic standards. Quantification was performed using isotope labeled $\left({ }^{13} \mathrm{C}\right)$ standards of levoglucosan and galactosan. The limit of quantification for the method at a signal to noise ratio of ten is approximately $30 \mathrm{ng}$ injected of the individual MAs. The limit of detection for the method at a signal to noise ratio of three ranged from $1.2-3.0 \mathrm{ng} \mathrm{cm}^{-2}$ for the individual MAs.

\subsection{Measurement of arabitol, mannitol and trehalose}

The sugar-alcohols arabitol, mannitol and trehalose were quantified according to the method described by Yttri et al. (2007b), with a few modifications. Briefly, one punch $\left(1.0 \mathrm{~cm}^{2}\right)$ from the quartz fibre filter was soaked in $50 / 50$ acetonitrile/methanol $(1.5 \mathrm{ml})$ and subjected to ultrasonic agitation $(30 \mathrm{~min})$. Each filter was extracted twice. The extracted volumes were pooled, filtered through a syringe filter $(0.45 \mu \mathrm{m})$ to remove particulates and filter debris, and evaporated to dryness under an $\mathrm{N}_{2}$ atmosphere. The dry extract was redissolved in Milli-Q water $(100 \mu \mathrm{l})$ and isopropanol $(300 \mu \mathrm{l})$ prior to analysis. The analysis was performed by HPLC/HRMS-TOF analysis operated in the negative electrospray mode. The compounds were identified by comparison of retention time obtained by separation on a carbohydrate column (Prevail Carb ES Column-W, $250 \mathrm{~mm} \times 4.6 \mathrm{~mm}, 5 \mu$ ). The limit of quantification of the method at a signal to noise ratio of ten is approximately $30 \mathrm{ng}$ injected of the individual sugar-alcohols. Isotope labeled standard of glucose, purchased from Cambridge Isotope Laboratories, was used as internal standard for quantification of the sugar-alcohols. The limit of detection of the method at a signal to noise ratio of three ranged from $15-29 \mathrm{ng} \mathrm{cm}^{-2}$ for the individual sugar-alcohols.

\subsection{Measurement of pinic acid, organosulphates and nitrooxy-organosulphates}

The analysis generally followed the procedure described by Kristensen and Glasius (2011). Filter punches $\left(1 \mathrm{~cm}^{2}\right)$ were extracted in acetonitrile by ultra sonication for 20 minutes. Extracts were filtered through a Teflon filter $(0.45 \mu \mathrm{m})$ and evaporated to dryness in a flow of $\mathrm{N}_{2}$. The residue was re-dissolved in $200 \mu \mathrm{l} 0.1 \%$ acetic acid containing $3 \%$ acetonitrile. Sample extracts were analyzed by HPLC coupled through an electrospray ionization inlet (operated in negative mode) to a quadrupole time-of-flight mass spectrometer (microTOFq, Bruker Daltonics). The HPLC stationary phase was a Waters Atlantis T3 C18 column $(2.1 \times 150 \mathrm{~mm} ; 3 \mu \mathrm{m}$ particle size $)$. The mobile phase consisted of acetic acid $(0.1 \% \mathrm{v} / \mathrm{v})$ and acetonitrile with an overall gradient from $3 \%$ to $95 \%$ acetonitrile in $50 \mathrm{~min}$. The injection volume was $40 \mu \mathrm{l}$ and the flow rate was $0.2 \mathrm{ml} \mathrm{min}^{-1}$. Camphor sulphonic acid was used as recovery standard and deuterated adipic acid as injection standard. cis-Pinic acid was quantified using a commercial standard, while camphor sulphonic acid was used as a surrogate standard for organosulphate and nitrooxy organosulphate compounds. The limit of detection of the method was $2 \mathrm{ng} \mathrm{cm}^{-2}$ for pinic acid, organosulphates and nitrooxy-organosulphates.

\subsection{Measurement of cellulose}

Free cellulose was determined based on the enzymatic method described by Kunit and Puxbaum (1996). Free cellulose was assumed to be $72 \%$ of total cellulose. Filter aliquots of $2 \mathrm{~cm}^{2}$ were subjected to ultrasonic agitation $(45 \mathrm{~min})$ in a citric acid solution $(2.2 \mathrm{ml}, 0.05 \mathrm{M}$, $\mathrm{pH}=4.8)$ containing Thymol $(0.05 \%)$ to prevent bacterial growth. The cellulose was saccharified by two enzymes, Trichoderma reesei cellulase $(80 \mu \mathrm{l}, 10 \%)$ and Aspergillus Niger cellobiase $(80 \mu \mathrm{l}, 1 \%)$ for $24 \mathrm{~h}$ at $45^{\circ} \mathrm{C}$. The saccharification was stopped by denaturizing the enzymes at $80^{\circ} \mathrm{C}$. After centrifuging $(4000 \mathrm{rpm}, 20 \mathrm{~min})$ the supernatant was collected for determination of D-glucose using a modified test-combination (D-Glucose-HK, Megazyme, Ireland). Glucose was phosphorylated to glucose-6-phosphate, and subsequently oxidized by NADP to gluconate-6-phosphate (G-6-P), with the formation of NADPH, which is stoichiometrically proportional to the initial amount of D-glucose in the sample. NADPH was quantified by UV photometry at $340 \mathrm{~nm}$, read against distilled water. The samples content of free glucose was subtracted from the result. The limit of detection is $160 \mathrm{ng} \mathrm{cm}^{-2}$.

\subsection{Precursor specific SOA tracers}

A composited sample from the Birkenes site, including all four weeks of sampling, was analyzed for selected SOA tracers using the technique of Kleindienst et al., 2007). Samples were Soxhlet-extracted using dichloromethane/methanol (1:1). Prior to the extraction, $20 \mu \mathrm{g}$ each of cis-ketopinic acid and $\mathrm{d}_{50}$-tetracosane were added. Extracts were evaporated to dryness then derivatized with bis-(trimethylsilyl)-trifluoroacedimide ( $250 \mu \mathrm{l}$, with $1 \%$ TMCS) and pyridine $(100 \mu \mathrm{l})$. Samples were injected onto the ThermoQuest GC (Austin, TX) without reduction in volume. Separation was performed on a $60 \mathrm{~m}, 0.25 \mathrm{~mm}$ i.d., $0.25 \mu \mathrm{m}$ film thickness $\mathrm{RT}_{\mathrm{x}}-5 \mathrm{MS}$ column (Restek, Inc., Bellefonte, PA), using conditions described in detail by Jaoui et al. (2006). 
Mass spectral analysis of the actual tracer compounds has been described by Jaoui et al. (2005) and Kleindienst et al. (2007). Compounds used as tracers are the following:

1. Isoprene tracers: 2,3-dihydroxymethacrylic acid, 2methylthreitol, 2-methylerythritol,

2. $\alpha$-pinene tracers: 3-acetyl pentanedioic acid, 3-acetyl hexanedioic acid, 3-carboxy heptanedioic acid, 3-hydroxy glutaric acid, 4-isopropyl-1-,2-dihydroxy hexanol, 3-(2-hydroxy-ethyl)-2,2-dimethylcyclobutane-carboxylic acid, pinic acid, pinonic acid,

3. toluene tracer: 2,3-dihydroxy-4-oxopentanoic acid.

Since no standards exist for many of these compounds, the concentrations of all tracers were estimated assuming unity response relative to ketopinic acid (Jaoui et al., 2004). Analysis for the tracer compounds was conducted using a selected ion technique described earlier by Kleindienst et al. (2007). The limits of detection range from 6 to $30 \mathrm{ng} \mathrm{cm}^{-2}$ for the precursor specific SOA tracers.

\subsection{Quality assurance}

The filter samples were collected according to the QBQ (Quartz fibre filter Behind Quartz fibre filter) approach, which provides a quantitative estimate of the positive sampling artefact of OC (McDow and Huntzicker, 1990; Turpin et al., 1994). The rather high filter face velocity $\left(50-54 \mathrm{~cm} \mathrm{~s}^{-1}\right)$, and the fact that negative artifacts are not accounted for by this approach suggests that the corrected levels of $\mathrm{OC}\left(\mathrm{OC}_{\mathrm{p}}\right)$ should be considered conservative. In the present study, the mean positive sampling artifact of OC ranged from $11 \pm 2 \%$ at the Finnish site Hyytiälä to $18 \pm 4 \%$ at the Birkenes site in Norway, which is in accordance with what has been reported previously (see Yttri et al., 2007 and references therein). The identical filter face velocity of the four samplers further increases the comparability, in particular with respect to OC and TC.

All analyses were performed within 6 months after the samples had been collected.

Thermal-optical analysis of EC and OC were performed according to the EUSAAR 2 thermal program, which is designed to reduce the inherited uncertainties associated with splitting of EC and OC, e.g. by preventing premature burn-off of EC (Cavalli et al., 2010). While all other chemical analysis was performed at centralized laboratories, the EC/OC analysis was performed at four different laboratories. To ensure comparability, an inter comparison was conducted, distributing four aliquots cut from the same filter amongst the four laboratories. The samples' contents of TC were reproduced within an accuracy of $5 \%$ amongst the four laboratories. For OC $(9 \%)$, and in particular for EC $(23 \%)$, the deviation was larger. It is found that this deviation was attributed solely to the DRI (Desert Research Institute) instrument at one of the participating laboratories, which gave lower EC than the SUNSET lab instruments used elsewhere. For the three other laboratories, the consistency in determining $\mathrm{EC}$ was within $<4 \%$. The $\mathrm{EC}$ level of the samples analyzed at the actual laboratory has been adjusted according to the finding of the inter comparison; i.e. to be comparable to the results obtained by the three SUNSET lab instruments.

The extended uncertainty associated with measurements of monosaccharide anhydrides and sugar-alcohols is found to range within 10-15\%, while for measurements of pinic acid the uncertainty is $<25 \%$.

Quantification of organosulphates and nitrooxy organosulphates was done using a surrogate standard. This adds uncertainty to the absolute concentrations of the various organosulphates and nitrooxy organosulphates, but it will not affect the relative concentrations. An inter comparison of organosulphates and nitrooxy organosulphates involving Aarhus University and CalTech (USA) (J. Surratt, personal communication, 2011) showed good agreement with respect to identification and linearity, but a 5-10 times underestimation of absolute concentrations at Aarhus University due to the use of a surrogate standard instead of authentic standards (Kristensen and Glasius, 2011). Authentic standards are not commercially available for organosulphates and nitrooxy organosulphates. The detection limit for the surrogate standard camphor sulfonic acid was $0.51 \mathrm{ng}$ injected (Kristensen and Glasius, 2011), which corresponds to about $0.015 \mathrm{ng} \mathrm{m}^{-3}$ for organosulphates and nitrooxy organosulphates in the present study.

The secondary standards (2 IAEA-C6 and 2 IAEA-C7) analyzed along with the ambient samples during ${ }^{14} \mathrm{C}$ analyses were all within 1 standard deviation of the consensus values.

\section{Meteorology and surface types}

\subsection{Meteorological conditions}

The month of August was chosen due to our focus on the natural sources of the carbonaceous aerosol. As illustrated by Andersson-Sköld and Simpson (2001), this is the month likely to produce the highest emissions of biogenic volatile organic compounds which subsequently provide the highest levels of biogenic secondary organic aerosols (BSOA) for Nordic areas. Certain sources of primary biological aerosol particles, e.g. release of fungal spores, are also likely to be particularly active in late summer/early fall (Yttri et al., 2007b).

The weather pattern at the start of the campaign was characterized by an anticyclone located over Scandinavia. Largely stagnant conditions and slight advection from the east or south-east led to accumulation of aerosols for the 

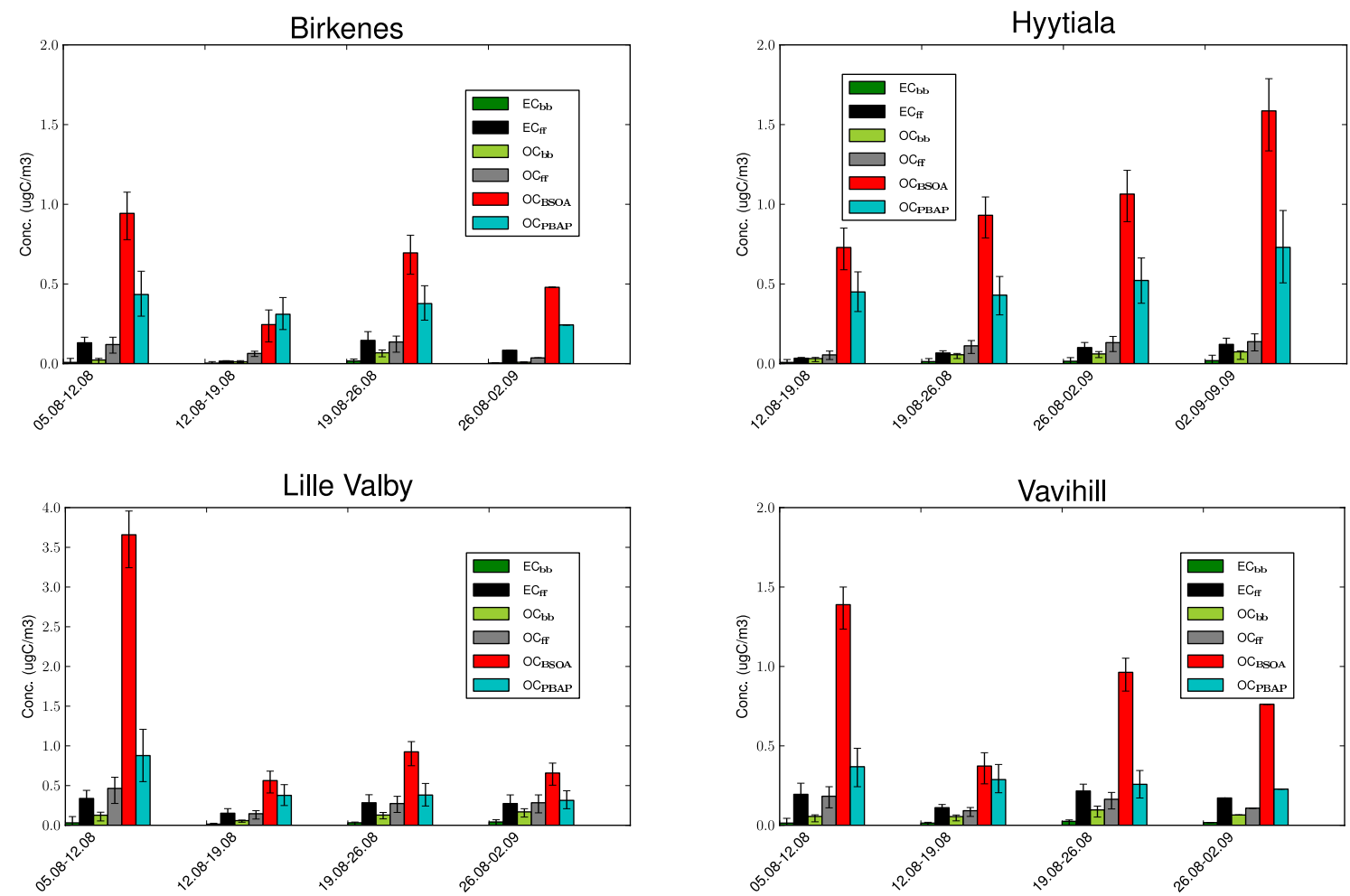

Fig. 2. Best estimate, i.e. 50 percentile, concentrations $\left(\mu \mathrm{g} \mathrm{m}^{-3}\right)$ of different carbonaceous particle fractions for the Birkenes, Hyytiälä, Lille Valby, and Vavihill filter samples, $\mathrm{PM}_{10}$. Uncertainty bars represent 10 and 90 percentiles from LHS calculations (not given when LHS solution rate $<10 \%$ ). Note the different scale on the y-axis for the Lille Valby site; and that sampling started one week later at the Hyytiälä site.

stations Birkenes, Lille Valby and Vavihill. Sampling at Hyytiälä started a week later and so did not include this period. On 10 August, the anticyclone weakened and retreated to the south, and from 11 August, the air sampled at the three western stations arrived from the west, with cyclones passing mainly north of the stations. This circulation pattern prevailed throughout the time period of the second sample (12-19 August), explaining the drop in concentrations between the first and second sampling period (see Fig. 2). At Hyytiälä, the westerly flow started a day later, on 12 August, when also the first sampling period began. During the third week of sampling (19-26 August), the anticyclone over Central Europe started extending towards the north again and carbonaceous aerosol concentrations increased at all four sites. The advection, however, was still mainly from the west, thus, concentrations did not reach the high levels of the first sampling week. Passing cyclones and westerly winds also influenced the stations from 26 August to 2 September when low concentrations were observed again at the three western stations. Hyytiälä still received air from the south (Eastern Europe) from the beginning of the sampling until 28 August, which seems to explain the higher measured concentrations at this station. During the final week of sampling at Hyytiälä, cyclonic influence was still predominant. However, air flow was on two occasions from the south ahead of passing cyclones, advecting air masses from Eastern Europe to the site.

Meteorological data from the four measurement sites showed that the ambient temperature, the relative humidity and precipitation amount during the sampling period was comparable to preceding years, hence the sampling period is likely to be representative for this time of the year.

\subsection{Surface type}

The surface type and land use is likely to play a crucial role for the ambient aerosol concentration, its chemical composition and physical properties. With output from the FLEXPART model (Stohl et al., 2005) we are able to define footprint sensitivities to various surface types and land use categories. For this analysis we have developed a new set of FLEXPART output products that utilize The Community Noah Land-Surface Model (Noah LSM; Mitchell, 2005). The Noah LSM provides land surface classifications gridded at $0.5 \mathrm{deg}$. resolution. The thirteen land surface types are based on the Vegetation Types ("SiB-1") after Dorman and Sellers (1989). Of the thirteen types, we have only included the seven largest contributors, whereas the rest are included as Other. 
To generate surface-type specific information, the FLEXPART global footprint emission sensitivity product is folded with the globally gridded surface types, i.e. emission sensitivities are considered only for the specific surface type considered and set to zero for all other surface types. In Fig. 3 we show the surface type sensitivity time series. This figure shows the relative air mass exposure to each of the surface types for the period of measurement observation. It should be noted that the NOAH LSM land use categories, used to define the surface types, are static and thus do not include seasonality nor changes over time.

The marine footprint totally dominated at all four sites but was more pronounced for the Birkenes, Lille Valby and Vavihill sites $(92 \pm 1.7 \%)$, which are all situated less than $25 \mathrm{~km}$ from the coast, than for the more continental site Hyytiälä ( $89 \%), 65 \mathrm{~km}$ from the coast (Fig. 3). The major terrestrial surface types were Needleleaf evergreen (e.g. pine and spruce), Agricultural and Tundra. For the three sites situated less than $25 \mathrm{~km}$ from the coast there were only minor differences in the relative contribution of the three major terrestrial categories; i.e. Agricultural $(33 \pm 3.5 \%$; Mean \pm SD), Needleleaf evergreen $(29 \pm 1.5 \%)$, and Tundra $(24 \pm 2.6 \%)$. The Needleleaf evergreen category (58\%) totally dominated at the more continental site Hyytiälä, followed by Tundra (16\%) and Agricultural (12\%). The Mixed forest and Needleleaf evergreen categories were found to be increased at the three sites located less than $25 \mathrm{~km}$ from the coast during the first week of sampling. This was particularly pronounced for the mixed forest category accounting for $14 \pm 2.4 \%$ during week 1 compared to $3.2 \pm 1.7 \%$ for the rest of the period. The corresponding percentages for the Needleleaf evergreen category was $43 \pm 6.1 \%$ (week 1) and $25 \pm 5.8 \%$ (week 2-4).

\section{Source apportionment using Latin Hypercube Sampling (LHS)}

A tracer methodology is used to provide source apportionment of the total carbon into different source categories. This methodology, originally developed for the CARBOSOL project (Gelencsér et al., 2007), has been refined for new measurements and Nordic conditions, and previously applied by Szidat et al. (2009) for Gothenburg, Sweden, and Yttri et al. (2011) for two sites in Norway. Indeed, the methodology used here is identical to that used by Yttri et al. (2011), and so only a brief description is given here.

In summary, measurements of levoglucosan are used as a tracer of wood-burning emissions $\left(\mathrm{TC}_{\mathrm{bb}}=\mathrm{OC}_{\mathrm{bb}}+\mathrm{EC}_{\mathrm{bb}}\right.$; $\mathrm{OC}_{\mathrm{bb}}$ includes primary and secondary $\mathrm{OC}$ ), mannitol and cellulose are used as tracers of primary biological aerosol particles $\left(\mathrm{OC}_{\mathrm{PBAP}}\right)$ derived from fungal spores $\left(\mathrm{OC}_{\mathrm{pbs}}\right)$ and plant debris $\left(\mathrm{OC}_{\mathrm{pbc}}\right)$, respectively. The ${ }^{14} \mathrm{C}$ isotopic ratios $\left(\mathrm{F}^{14} \mathrm{C}\right)$ are used along with the measured $\mathrm{OC}$ and $\mathrm{EC}$ and assumed emission ratios (e.g. $\mathrm{TC}_{\mathrm{bb}} /$ levoglucosan and $\mathrm{OC}_{\mathrm{bb}} / \mathrm{TC}_{\mathrm{bb}}$ from wood combustion, or OC/EC ratios from fossil-fuel combustion), to assign the remaining carbon between fossil-fuel sources and secondary organic aerosol sources. Total carbon is in this way split into $\mathrm{TC}_{\mathrm{bb}}, \mathrm{OC}_{\mathrm{PBAP}}, \mathrm{TC}_{\mathrm{ff}}\left(=\mathrm{OC}_{\mathrm{ff}}+\mathrm{EC}_{\mathrm{ff}}\right.$, from fossil-fuel sources; $\mathrm{OC}_{\mathrm{ff}}$ includes primary and secondary $\mathrm{OC}$ ), and finally any remaining modern-carbon is assumed to be $\mathrm{OC}_{\mathrm{BSOA}}$ (biogenic secondary organic aerosol).

The relationship between any tracer and its derived TC component is very uncertain, and so we have assigned an uncertainty distribution of allowed parameter values for all important emission ratios or measurement inputs. In order to solve the system of equations, allowing for the multitude of possible combinations of parameters, an effective statistical approach known as Latin-hypercube sampling (LHS) is used, which is comparable to Monte Carlo calculations. Details of this procedure were first given by Gelencser et al. (2007), and the procedure as used here is described in detail in Yttri et al. (2011). In brief, central values with low and high limits are associated to all uncertain input parameters. These factors are combined using a simplified approach of LHS in order to generate thousands of solutions for the source-apportionment. All valid combinations of parameters (i.e. excluding those producing negative solutions) are condensed in frequency distributions of possible solutions. Extensive discussion of the choices behind the factors used, and their uncertainties, can be found in earlier related studies: Szidat et al. (2009), Gelencser et al. (2007) and, for wood-burning emissions, Simpson et al. (2007).

The result of this analysis consist of so-called bestestimates of the TC components (i.e. the 50th percentile), as well as the range of possibilities allowed by the LHS calculation, usually expressed as the 5th and 95th percentiles of the solutions.

\section{Results}

\subsection{Ambient concentrations of $\mathrm{EC}$ and $\mathrm{OC}_{\mathrm{P}}$}

Mean concentrations of elemental carbon (EC), positiveartifact-corrected particulate organic carbon $\left(\mathrm{OC}_{\mathrm{p}}\right)$, organic carbon on backup filters $\left(\mathrm{OC}_{\mathrm{B}}\right)$, particulate total carbon $\left(\mathrm{TC}_{\mathrm{p}}\right)$, and $\mathrm{EC} / \mathrm{TC}_{\mathrm{p}}$ ratios for $\mathrm{PM}_{10}$ are presented in Table 2. The levels appear to be in the lower range of that previously reported for the Nordic rural background environment during summer (Yttri et al., 2007a), however different sampling-times and techniques are likely to contribute at least partly to the observed differences. Within Europe, the Nordic countries typically experience the lowest carbonaceous aerosol loading (Yttri et al., 2007a). The rather low mean $\mathrm{EC} / \mathrm{TC}_{\mathrm{p}}$ ratio $(14 \pm 8.2 \%$; for all four sites) is consistent with a modest anthropogenic influence. The $\mathrm{EC} / \mathrm{TC}_{\mathrm{p}}$ ratio was particularly low at the Finnish site 

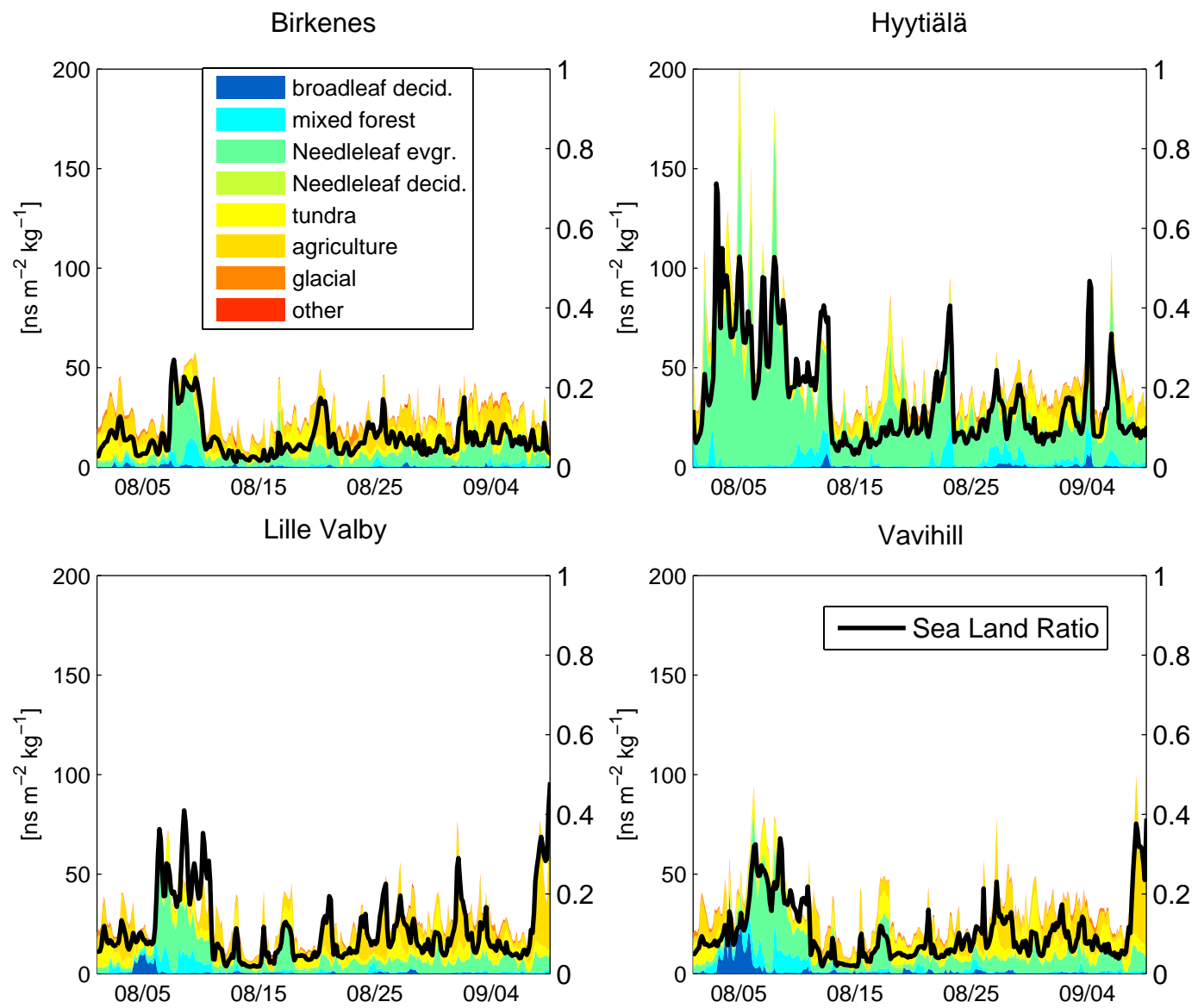

Fig. 3. Time series plots showing the footprint emissions sensitivity to the Noah LSM vegetation types for the sites Birkenes (Norway), Hyytiälä (Finland), Lille Valby (Denmark) and Vavihill (Sweden) for the period 5 August-9 September 2009. Note that of the thirteen land surface types we only plot the seven largest contributors and include the rest as Other. The black line is the ratio of land to ocean contribution, showing that the bulk of the measured air mass at these sites is of Marine origin.

Hyytialä $(5.6 \pm 1.5 \%)$ compared to the ratio observed at Vavihill $(23 \pm 6.0 \%)$ and Lille Valby $(17 \pm 6.6 \%)$.

\subsection{Ambient concentrations of organic tracers}

Ambient mean concentrations of levoglucosan, mannosan, galactosan, mannitol, arabitol, trehalose, cellulose, pinic acid and selected organo-sulphates in $\mathrm{PM}_{10}$ are reported in Table 2. The mean concentration of levoglucosan was low, $<10 \mathrm{ng} \mathrm{m}^{-3}$ at all sites, suggesting that emissions from wood burning was a minor contributor to the carbonaceous aerosol loading during the study period. Levoglucosan was the major monosaccharide anhydride (MA), accounting for $83 \pm 4 \%$ of the sum of the three MA quantified (i.e. levoglucosan, mannosan and galactosan). Levels of the fungal spore tracers mannitol, arabitol, and trehalose were within the range reported previously for the Scandinavian (Yttri et al., 2007b; Carvalho et al., 2003) and the continental European (Ion et al., 2005) rural background environment, however only a very few studies have reported such measurements. A high correlation $\left(r^{2}>0.93\right)$ between the three sugar alcohols emphasises their common origin and thus their suitability as fungal spore tracers. Pinic acid concentrations were all less than $10 \mathrm{ng} \mathrm{m}^{-3}$, which are similar to concentrations reported by Zhang et al. (2010, and references therein) for measurements conducted in Europe.

The content of cellulose in the ambient aerosol has only been reported in a very few studies (Kunit and Puxbaum, 1996; Puxbaum and Tenze-Kunit, 2003; Sanchez-Ochoa et al., 2007). The mean cellulose concentrations observed in the present study, ranging from $89-342 \mathrm{ng} \mathrm{mm}^{-3}$, are comparable to those observed for the European rural background environment by Sanchez-Ochoa et al. (2007).

A number of the selected SOA tracers sought for as described in Sect. 2.9 (see Table 3) were identified in a composited sample from the Birkenes site, confirming their presence also in the Nordic rural background environment. The sum of the three isoprene tracers was found at a concentration of $1.5 \mathrm{ng} \mathrm{m}^{-3}$, whereas the toluene tracer and the $\beta$-caryophyllene tracer were not observed above limits 
Table 2. Mean $( \pm \mathrm{SD})$ concentrations of carbonaceous sub-fractions and selected organic compounds in $\mathrm{PM}_{10}$. The EC-to-TC $\mathrm{p}$ ratio and the fraction modern carbon $\left(\mathrm{F}^{14} \mathrm{C}\right)$ of $\mathrm{TC}$, based on ${ }^{14} \mathrm{C} /{ }^{12} \mathrm{C}$ - analysis, are also listed. b.d. means below detection limit.

\begin{tabular}{|c|c|c|c|c|c|}
\hline & & Birkenes (Norway) & Hyytiälä (Finland) & Lille Valby (Denmark) & Vavihill (Sweden) \\
\hline $\mathrm{TC}_{\mathrm{P}}$ & & $0.96 \pm 0.38$ & $1.7 \pm 0.54$ & $2.4 \pm 1.9$ & $1.4 \pm 0.48$ \\
\hline $\mathrm{OC}_{\mathrm{P}}$ & & $0.84 \pm 0.32$ & $1.6 \pm 0.49$ & $2.1 \pm 1.8$ & $1.1 \pm 0.45$ \\
\hline $\mathrm{OC}_{\mathrm{B}}$ & & $0.19 \pm 0.10$ & $0.20 \pm 0.05$ & $0.24 \pm 0.05$ & $0.17 \pm 0.05$ \\
\hline $\mathrm{EC}$ & & $0.12 \pm 0.07$ & $0.10 \pm 0.05$ & $0.32 \pm 0.09$ & $0.30 \pm 0.08$ \\
\hline $\mathrm{EC} / \mathrm{TC}_{\mathrm{P}}$ & & $12 \pm 6.9$ & $5.6 \pm 1.5$ & $17 \pm 6.6$ & $23 \pm 6.0$ \\
\hline $\mathrm{F}^{14} \mathrm{C} \mathrm{TC}$ & & $0.93 \pm 0.03$ & $0.99 \pm 0.03$ & $0.83 \pm 0.08$ & $0.8 \pm 0.02$ \\
\hline \multicolumn{6}{|l|}{ Unit: $\left(\mathrm{ng} \mathrm{m}^{-3}\right)$} \\
\hline Levoglucosan & & $2.1 \pm 2.1$ & $4.6 \pm 1.5$ & $9.8 \pm 3.7$ & $5.6 \pm 1.7$ \\
\hline Mannitol & & $16 \pm 4.7$ & $30 \pm 8.2$ & $17 \pm 7.3$ & $13 \pm 3.5$ \\
\hline Trehalose & & $5.8 \pm 2.6$ & $13 \pm 4.1$ & $4.8 \pm 2.7$ & $6.4 \pm 3.6$ \\
\hline Cellulose & & $89 \pm 20$ & $133 \pm 43$ & $172 \pm 113$ & $86 \pm 16$ \\
\hline Pinic Acid & & $3.2 \pm 1.5$ & $6.2 \pm 2.7$ & $2.4 \pm 0.61$ & $2.8 \pm 1.3$ \\
\hline Organo-sulphate & $(\mathrm{MW}=216)$ & $0.80 \pm 1.2$ & $1.2 \pm 1.6$ & $0.27 \pm 0.14$ & $0.24 \pm 0.14$ \\
\hline Organo-sulphate & $(\mathrm{MW}=250)$ & $0.05 \pm 0.09$ & $0.08 \pm 0.15$ & b.d. & b.d. \\
\hline Organo-sulphate & $(\mathrm{MW}=264)$ & b.d. & $0.05 \pm 0.03$ & $0.05 \pm 0.06$ & b.d. \\
\hline Organo-sulphate & $(\mathrm{MW}=280)$ & b.d. & $0.10 \pm 0.13$ & b.d. & b.d. \\
\hline Nitrooxy-organo-sulphate & $(\mathrm{MW}=295)$ & $0.38 \pm 0.42$ & $0.75 \pm 0.35$ & $0.85 \pm 0.74$ & $0.74 \pm 0.58$ \\
\hline Nitrooxy-organo-sulphate & $(\mathrm{MW}=297)$ & $0.52 \pm 0.59$ & $1.2 \pm 0.68$ & $1.5 \pm 2.4$ & $1.2 \pm 1.6$ \\
\hline
\end{tabular}

of detection of approximately $0.1 \mathrm{ng} \mathrm{m}^{-3}$. The sum of eight $\alpha$-pinene tracers was $14 \mathrm{ng} \mathrm{m}^{-3}$, which is significantly lower than the levels previously reported by this technique in the US and in Hong Kong (Offenberg et al., 2011; Kleindienst et al., 2007; Lewandowski et al., 2008; Hu et al., 2008), as well as in France (El Haddad et al., 2011).

\subsection{Ambient concentrations of organosulphates and nitrooxy organosulphates}

Only three studies have reported ambient aerosol concentrations of speciated organosulphates and nitrooxyorganosulphates in Europe (Gómez-Gonzalez et al., 2008; Iinuma et al., 2007; Kristensen and Glasius, 2011), of which two reported concentrations for the rural background environment, i.e. at K-Puszta (Hungary) and in Waldstein (Fichtelgebirge, Germany). Thus, the present study substantially expands the knowledge of speciated organosulphates and nitrooxy organosulphates in Europe, reporting results from four sites which represent various subcategories of the Nordic rural background environment. In addition, the current study covers one of the longest measurement periods reported so far.

Only four organosulphates and two nitrooxy organosulphates were identified in the samples, which probably reflects the rather small filter punch available for each type of analysis. The organosulphate resulting from oxidation of isoprene $(\mathrm{MW}=216)$ was found at higher concentrations $\left(0.24-1.2 \mathrm{ng} \mathrm{m}^{-3}\right)$ than previously reported for a study conducted in Denmark during spring $\left(\sim 0.01 \mathrm{ng} \mathrm{m}^{-3}\right)$ (Kristensen and Glasius, 2011), but still much lower compared to levels reported for the Southeastern USA; e.g. $64 \mathrm{ng} \mathrm{m}^{-3}$ reported by Chan et al. (2010). Three organosulphates from monoterpenes (MW =250, 264 and 280) were identified, of which those with a molecular weight of 250 and 280 were present at concentrations comparable to that reported by Kristensen and Glasius (2011). In contrast, concentrations of nitrooxy organosulphates originating from $\alpha$-pinene and $\beta$-pinene (MW =295) and from limonene ( $\mathrm{MW}=297)$ were several times higher in the present study compared to the previous study by Kristensen and Glasius (2011). 
Table 3. Concentrations of SOA tracers in a four week composited $\mathrm{PM}_{10}$ filter sample at the Birkenes site (Norway). Unit: $\mathrm{ng} \mathrm{m}^{-3}$. b.d. means below detection limit.

\begin{tabular}{lr}
\hline & Birkenes (Norway) \\
\hline Isoprene tracers & \\
\hline 2,3-dihydroxymethacrylic acid & 0.70 \\
2-methylthreitol & 0.28 \\
2-methylerythritol & 0.49 \\
\hline$\alpha$-pinene tracers & \\
\hline 3-acetyl pentanedioic acid & b.d. \\
3-acetyl hexanedioic acid & 0.96 \\
3-carboxy heptanedioic acid & 5.2 \\
3-hydroxy glutaric acid & 4.9 \\
4-isopropyl-1-,2-dihydroxy hexanol & 2.5 \\
3-(2-Hydroxy-ethyl)-2,2-dimethyl- & b.d. \\
cyclobutane-carboxylic acid & \\
Pinic acid & 0.33 \\
Pinonic acid & b.d. \\
\hline Toluene tracer & \\
\hline 2,3-dihydroxy-4-oxopentanoic acid & b.d. \\
$\beta$-caryophyllene tracer & b.d. \\
$\beta$ - caryophyllinic acid &
\end{tabular}

\section{$5.4 \quad F^{14} \mathrm{C}$ TC}

The results from the ${ }^{14} \mathrm{C}$ measurements of $\mathrm{TC}$ in $\mathrm{PM}_{10}$ are presented in Table 2 as $\mathrm{F}^{14} \mathrm{C}$ values (Reimer et al., 2004). The $\mathrm{F}^{14} \mathrm{C}$ values at the Danish site Lille Valby (0.83) and the Swedish site Vavihill (0.87) are similar to the levels reported from rural sites in continental Europe (Gelencsér et al., 2007; May et al., 2009). The Finnish and Norwegian sites (Hyytiälä and Birkenes) display slightly higher ${ }^{14} \mathrm{C}$ concentrations ( $\mathrm{F}^{14} \mathrm{C}$ values of 0.99 and 0.93 , respectively) compared to the other two sites, and are comparable to the upper range of $\mathrm{F}^{14} \mathrm{C}$ values reported by Yttri et al. (2011) for the Norwegian rural background environment. Reported values from urban sites in Europe show significantly higher fossil impact $\left(\mathrm{F}^{14} \mathrm{C}\right.$ values of $\left.0.60-0.73, p<0.01\right)$ (Szidat et al., 2004, 2006 and 2009; Yttri et al., 2011).

\section{Discussion}

The results of the source-apportionment analysis, presented in Figs. 2 and 4 (and Tables S1-S8), show that natural sources, and BSOA in particular, totally dominated the carbonaceous aerosol loading in the Nordic rural background environment during summer. The various carbonaceous components are discussed in detail in Sects. 6.1-6.5. In Sect. 6.6 we present a brief overview of the biogenic oxidation products.
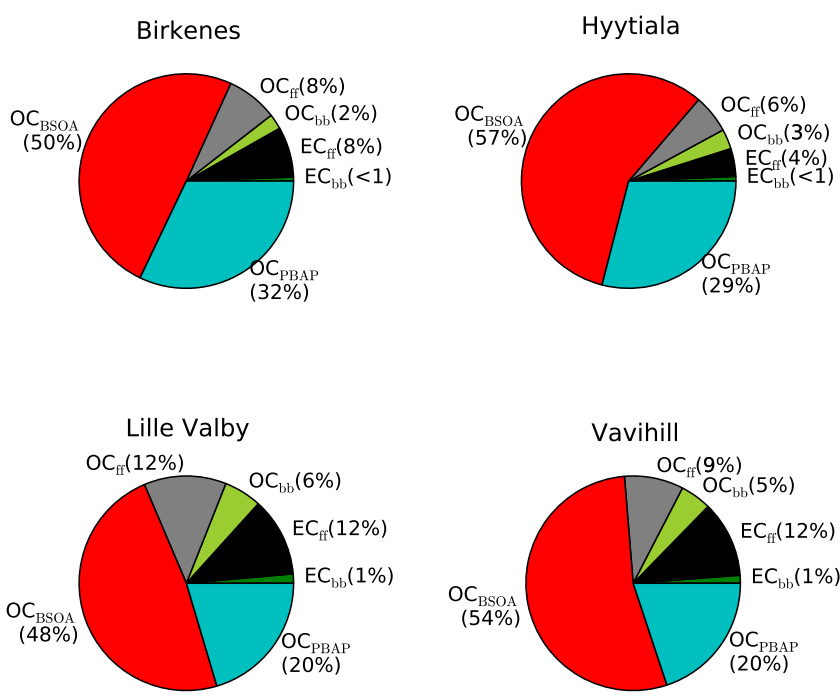

Fig. 4. Best estimate, i.e. 50 percentile, percentage contributions of different carbonaceous particle fractions to $\mathrm{TC}_{\mathrm{p}}$ for Birkenes, Hyytiälä, Lille Valby, and Vavihill filter samples $\left(\mathrm{PM}_{10}\right)$ from LHS analysis.

\subsection{Carbonaceous aerosol from fossil-fuel sources and biomass burning}

The mean concentration of OC from fossil-fuel sources $\left(\mathrm{OC}_{\mathrm{ff}} ; 0.1-0.3 \mu \mathrm{g} \mathrm{C} \mathrm{m}^{-3}\right.$ ) was higher than $\mathrm{OC}$ from wood burning $\left(\mathrm{OC}_{\mathrm{bb}} ; \leq 0.1 \mu \mathrm{g} \mathrm{C} \mathrm{m}^{-3}\right)$ at all sites throughout the sampling period. The highest mean concentrations were observed in Lille Valby both with respect to $\mathrm{OC}_{\mathrm{ff}}$ and $\mathrm{OC}_{\mathrm{bb}}$, being a factor 2-3 higher compared to the three other sites. On a weekly basis, $\mathrm{OC}_{\mathrm{ff}}$ did not exceed $0.5 \mu \mathrm{g} \mathrm{m}^{-3}$ at any of the sites, whereas $\mathrm{OC}_{\mathrm{bb}}$ stayed below $0.2 \mu \mathrm{g} \mathrm{C} \mathrm{m}^{-3}$. The mean relative contribution of $\mathrm{OC}_{\mathrm{ff}}$ to $\mathrm{TC}_{\mathrm{p}}$ ranged from $6 \%$ in Hyytiälä to $12 \%$ at Lille Valby, whereas the corresponding range for $\mathrm{OC}_{\mathrm{bb}}$ was $2 \%$ (Birkenes) to $6 \%$ (Lille Valby). These low percentages clearly demonstrate that $\mathrm{OC}$ from combustion of biomass and fossil-fuel sources are minor contributors to the carbonaceous aerosol loading in the Scandinavian rural background environment in summer. Fossil fuel sources were the major contributor to EC at all four sites. The mean $\mathrm{EC}_{\mathrm{ff}}$ concentration ranged from approximately $0.1 \mu \mathrm{g} \mathrm{C} \mathrm{m}^{-3}$ to $0.3 \mu \mathrm{g} \mathrm{C} \mathrm{m}^{-3}$, whereas for $\mathrm{EC}_{\mathrm{bb}}$ the mean concentrations was $<0.03 \mu \mathrm{g} \mathrm{C} \mathrm{m}^{-3}$. The highest mean concentrations of $\mathrm{EC}_{\mathrm{bb}}$ and $\mathrm{EC}_{\mathrm{ff}}$ were both observed at Lille Valby. For $\mathrm{EC}_{\mathrm{ff}}$ the mean relative contribution to $\mathrm{TC}_{\mathrm{p}}$ ranged from 4-12\%, whereas for $\mathrm{EC}_{\mathrm{bb}}$ it was $<1.5 \%$ at all sites.

A moderately high correlation coefficient $\left(r^{2}=0.5\right)$ observed between the $\mathrm{EC} / \mathrm{TC}_{\mathrm{p}}$ ratio and the Agricultural land use category could suggest that late summer agricultural activity, e.g. harvesting, agricultural waste burning, has an impact on the EC levels observed in the Nordic rural 
background environment. The very low $\mathrm{EC}_{\mathrm{bb}}$ levels observed indicated that agricultural waste burning is of minor importance, though, suggesting that e.g. tractors and off-road machinery is the source of high EC fractions.

\subsubsection{Wild fire contribution to $\mathrm{OC}_{\mathrm{ff}}$ and $\mathrm{EC}_{\mathrm{ff}}$}

Measurements of levoglucosan alone cannot differentiate between emissions from residential wood burning and wild/agricultural fires. Thus, we have applied the FLEXPART carbon monoxide CO passive fire tracer (Stohl et al., 2007) to address the influence of wild/agricultural fires, and find that all sites have a certain influence from this source, although the $\mathrm{CO}$ passive fire tracer levels are quite low (i.e. peak levels below $30 \mathrm{ppb}$ ). Elevated CO passive fire tracer levels were typically the results of fire emissions more than 10 days prior to arrival of the air mass at the measurement site, thus wet and dry deposition were likely to have depleted the aerosol particle concentration substantially. Further, the aerosol particle concentration of levoglucosan might be selectively depleted by $\mathrm{OH}$ during long range transport, particularly during summer, thus underestimating levels of $\mathrm{EC}_{\mathrm{bb}}$ and $\mathrm{OC}_{\mathrm{bb}}$. Although levoglucosan containing aerosol from wild/agricultural fires is deposited during atmospheric transport, co-emitted semi-volatile organic compounds (SVOCs) can be present at the receptor point. This will cause an underestimation of the $\mathrm{EC}_{\mathrm{bb}}$ and $\mathrm{OC}_{\mathrm{bb}}$ levels, as well as adding to the level of $\mathrm{OC}_{\mathrm{BSOA}}$, according to the approach described in section 4 . Nevertheless, there appears to be an association between $\mathrm{CO}$ passive fire tracer levels associated with more recent air masses (atmospheric residence time $<5$ days) influenced by wild/agricultural fires and levoglucosan. This becomes apparent when superimposing the weekly time resolution time series of levoglucosan on that of the $\mathrm{CO}$ passive fire tracer, as seen in Fig. 5. Further, the negative correlation observed between the biomass burning tracer levoglucosan and $\mathrm{F}^{14} \mathrm{C}$, suggest that other sources than biomass burning were driving the $\mathrm{F}^{14} \mathrm{C}$ values (here: $\mathrm{OC}_{\mathrm{BSOA}}$ and $\mathrm{OC}_{\mathrm{PBAP}}$ ).

\subsection{Biogenic secondary organic aerosol, $\mathrm{OC}_{\mathrm{BSOA}}$}

$\mathrm{OC}_{\mathrm{BSOA}}$ was the major contributor to the carbonaceous aerosol at all four sites, accounting for $48-57 \%$ of $\mathrm{TC}_{\mathrm{p}}$ on average during the one month sampling period. The highest relative contribution was observed for the Finnish site Hyytiälä and the lowest for the Danish site Lille Valby. The relative contribution of $\mathrm{OC}_{\mathrm{BSOA}}$ to TCP was remarkably stable in Hyytiälä, differing no more than $3 \%$ between the highest $(59 \%)$ and lowest $(56 \%)$ on a weekly basis, whereas the corresponding range was 20-30\% for the other three sites. The monthly mean $\mathrm{OC}_{\mathrm{BSOA}}$ concentration ranged from $0.6 \mu \mathrm{g} \mathrm{m}^{-3}$ at the Norwegian site Birkenes to $1.5 \mu \mathrm{g} \mathrm{m}^{-3}$ at Lille Valby. Substantial week-to-week variation in the $\mathrm{OC}_{\mathrm{BSOA}}$ concentration was observed; e.g. by a factor of 7 at Lille Valby. The higher $\mathrm{OC}_{\mathrm{BSOA}}$ concentrations at Lille Valby could possibly be a result of the higher $\mathrm{OC}_{\mathrm{p}}$ concentrations observed (Table 2), favouring condensation (Donahue et al., 2009), as otherwise we would expect similar source strength of BSOA as at Vavihill. The $\mathrm{OC}_{\mathrm{BSOA}}$ concentration range reported here corresponds well with that reported by Yttri et al. (2011) (i.e. $\mathrm{OC}_{\mathrm{BSOA}}=2.0-2.3 \mu \mathrm{g} \mathrm{C} \mathrm{m}{ }^{-3}$ ) for the Norwegian rural background environment during summer.

\subsection{Primary biological aerosol particles, OC PBAP}

In the present study, $\mathrm{OC}_{\mathrm{PBAP}}$ was accounted for by the sum of $\mathrm{OC}$ associated with fungal spores $\left(\mathrm{OC}_{\mathrm{pbs}}\right)$ and plant debris $\left(\mathrm{OC}_{\mathrm{pbs}}\right)$. The results show that $\mathrm{OC}_{\mathrm{PBAP}}$ comprised on average $20-32 \%$ of $\mathrm{TC}_{\mathrm{p}}$ during the actual sampling period, confirming that PBAP is an important source of the summer time carbonaceous aerosol in the Scandinavian rural background environment. The relative contribution of $\mathrm{OC}_{\mathrm{PBAP}}$ to $\mathrm{TC}_{\mathrm{p}}$ was noticeably higher at Birkenes $(32 \%)$ and in Hyytiälä (29\%) compared to Lille Valby and Vavihill (both $20 \%$ ). Consequently, PBAP was the second largest source of $\mathrm{TC}_{\mathrm{p}}$ next to $\mathrm{BSOA}$ at Birkenes, Hyytiälä and Vavihill, whereas it was slightly less than the joint contribution of EC and OC from fossil fuel sources at Lille Valby. In fact, $\mathrm{OC}_{\mathrm{PBAP}}$ accounted for twice the contribution made up by anthropogenic sources; i.e. the sum of EC and $\mathrm{OC}$ originating from combustion of biomass and fossil fuel sources at Birkenes and in Hyytiälä. With the exception of the second sampling week, the relative contribution of $\mathrm{OC}_{\mathrm{PBAP}}$ to $\mathrm{TC}_{\mathrm{p}}$ showed almost no variation for the four sites. $\mathrm{OC}_{\mathrm{pbc}}(12-18 \%)$ made a larger contribution to $\mathrm{TC}_{\mathrm{p}}$ than $\mathrm{OC}_{\mathrm{pbs}}(7-15 \%)$, except for Hyytiälä where their contributions were equally large. The monthly mean concentration level ranged from $0.3 \mu \mathrm{g} \mathrm{C} \mathrm{m}^{-3}$ at Birkenes and Vavihill to $0.5 \mu \mathrm{g} \mathrm{m}^{-3}$ at Hyytiälä and Lille Valby, whereas the highest weekly mean was close to $0.9 \mu \mathrm{g} \mathrm{C} \mathrm{m}^{-3}$. These concentration levels are comparable to the levels reported by Yttri et al. (2011; i.e. OC $\mathrm{PBAP}=0.9 \mu \mathrm{g} \mathrm{Cm}^{-3}$ ) for the Norwegian rural background environment. A correlation of $r^{2}=0.72$ was observed between $\mathrm{OC}_{\mathrm{BSOA}}$ and $\mathrm{OC}_{\mathrm{PBAP}}$ which mainly was attributed to the $\mathrm{OC}_{\mathrm{pbc}}$ fraction $\left(r^{2}=0.87\right)$ of OC $\mathrm{PBAP}$. This finding could support the suggestion made by Yttri et al. (2011) that PBAP might act as a condensational sink in areas where the carbonaceous aerosol from anthropogenic sources are scarce. However, PBAP was not found to be associated with BSOA to any particular degree in the Amazon, a region less perturbed by anthropogenic sources than the Nordic countries (Pöschl et al., 2010).

A pronounced correlation was observed between $\mathrm{OC}_{\mathrm{pbs}}$ and the Needleleaf evergreen surface category $\left(r^{2}=0.64\right)$, suggesting that areas with coniferous trees were important for the ambient aerosol concentration of fungal spores during late summer in the Nordic rural background environment. 

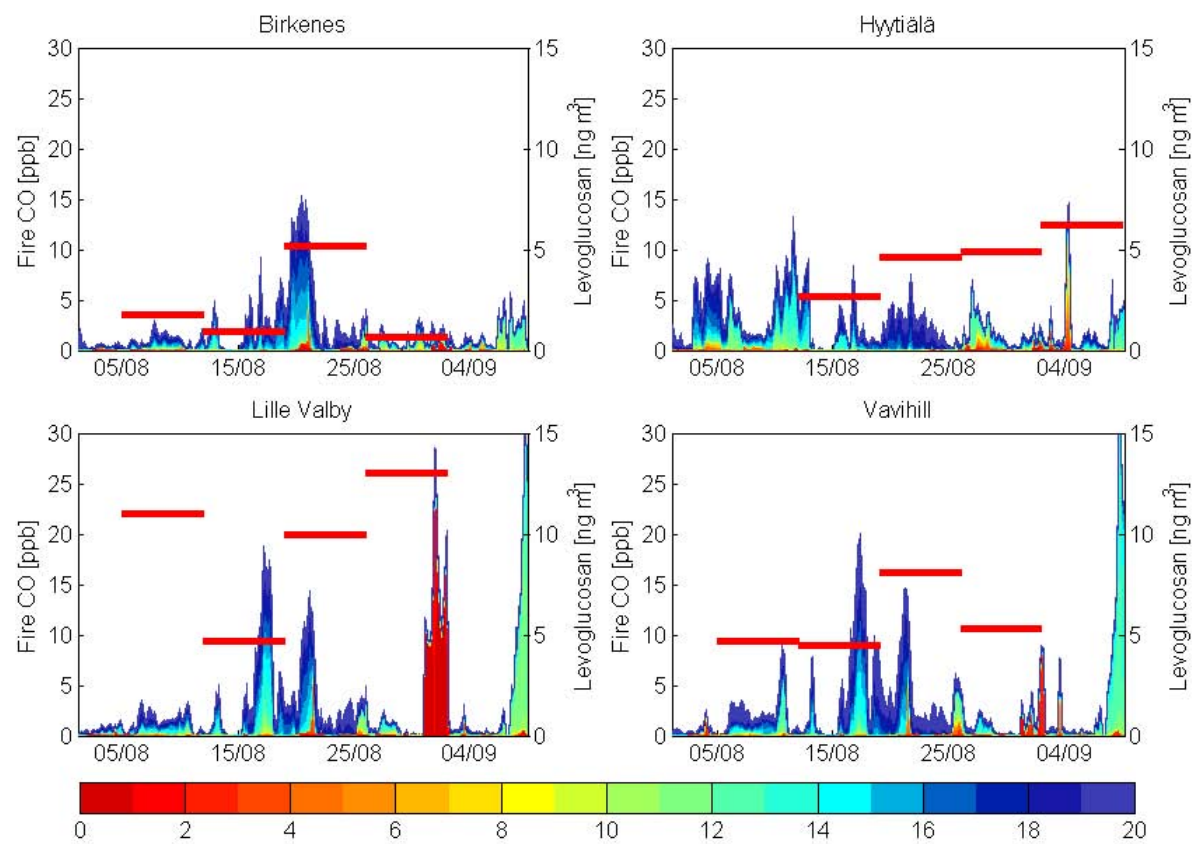

Fig. 5. Time series of observed levoglucosan concentrations (red horizontal bars) and CO wild/agricultural fire tracer mixing ratios (ppb) obtained from the FLEXPART backward simulations for Birkenes (Norway), Hyytiälä (Finland), Lille Valby (Denmark) and Vavihill (Sweden) for the period 5 August-9 September 2009. The colored bars correspond to the time (days) passed since emission at the fire locations

For $\mathrm{OC}_{\mathrm{pbc}}$ no pronounced correlation for any land use category was observed.

\subsection{Natural versus anthropogenic sources of the carbonaceous aerosol}

BSOA and PBAP are defined as natural sources, although anthropogenic emissions and activity may influence their levels. This includes air pollution enhancement of BSOA formation (Tsigaridis and Kanakidou, 2003; Carlton et al., 2010; Donahue et al., 2009; Hoyle et al., 2011), as well as increased levels of PBAP have been found to be associated with e.g. agricultural activities, sewage plants and building demolition (Matthias-Maser, 1998, and references therein). We define carbonaceous aerosol arising from fossil-fuel sources and biomass combustion $\left(\mathrm{EC}_{\mathrm{bb}}, \mathrm{EC}_{\mathrm{ff}}, \mathrm{OC}_{\mathrm{bb}}\right.$ and $\left.\mathrm{OC}_{\mathrm{ff}}\right)$ as anthropogenic emissions. Obviously, wild fires emissions can be categorized as natural in cases when ignited by lightning, as is the case for the major Boreal fires in Canada and Siberia (Stocks et al., 2002), but most incidences when natural vegetation catches fire in Europe is likely due to human activity (Winiwarter et al., 1999). In the present study, we found that increased levels of levoglucosan were associated with nearby wild fires (i.e. atmospheric residence time $<5$ days; see Fig. 5). Thus, for the sake of simplicity we categorize all emissions from wild fires as anthropogenic in the current study. Carbonaceous aerosol from natural sources was the major contributor to $\mathrm{TC}_{\mathrm{p}}$ by a fair margin at all four sites. The highest mean relative contribution was observed for the Finnish site Hyytiälä $(86 \%)$ and the lowest for the Danish site Lille Valby $(69 \%)$. The monthly mean concentration ranged from $0.9 \mu \mathrm{g} \mathrm{C} \mathrm{m}^{-3}$ at Birkenes to $1.9 \mu \mathrm{g} \mathrm{m}^{-3}$ at Lille Valby. On a weekly basis the natural contribution even reached $90 \%$ of $\mathrm{TC}_{\mathrm{p}}$ for the Hyytiäla site. The natural contribution was always dominated by $\mathrm{OC}_{\mathrm{BSOA}}$, except for one week at Birkenes during which $\mathrm{OC}_{\mathrm{PBAP}}$ prevailed. The highest relative contribution of carbonaceous aerosol from anthropogenic sources to $\mathrm{TC}_{\mathrm{p}}$ on a weekly basis was observed at Lille Valby, reaching $44 \%$, of which $32 \%$ was from fossil sources and $12 \%$ due to biomass burning. The monthly mean concentration of carbonaceous aerosol from anthropogenic sources ranged from $0.2 \mu \mathrm{g} \mathrm{C} \mathrm{m}^{-3}$ at Birkenes to $0.7 \mu \mathrm{g} \mathrm{C} \mathrm{m}{ }^{-3}$ at Lille Valby, thus showing somewhat greater variation between the sites than the contribution from natural sources.

\subsection{Consistency of results from LHS calculations}

The challenges associated with splitting $\mathrm{OC}_{\mathrm{PBAP}}, \mathrm{OC}_{\mathrm{bb}}$ and $\mathrm{OC}_{\mathrm{BSOA}}$ have been discussed in the literature (e.g. Yttri et al., 2011; Grieshop et al., 2009a, b). Grieshop et al. (2009a, b) showed that SOA from wood-burning actually may equal levels of POA, while a SOA/POA ratio of about 3.1 can be derived from the results of Heringa et al. (2011). The ratios used in the present study were derived from wintertime ambient measurements (Yttri et al., 2009), thus they may 
also include condensed vapors. By calculating $\mathrm{OC}_{\mathrm{pbc}}$ and $\mathrm{OC}_{\mathrm{pbs}}$, we have likely accounted for the two most important terrestrial PBAP sources that would otherwise introduce uncertainty into the calculation of $\mathrm{OC}_{\mathrm{BSOA}}$. On the other hand, Ceburnis et al. (2011) recently suggested a major impact of fine mode PBAP derived from plankton from the marine environment at Mace Head on the West coast of Ireland, which is not accounted for by the PBAP tracers used in the present study. In Sect. 3.2 it is shown that the marine footprint dominates at all four sites and that it is most pronounced at the Birkenes, Lille Valby and Vavihill sites which are all situated less than $25 \mathrm{~km}$ from the coastline. Thus, one cannot exclude the possibility that a certain fraction of the apportioned BSOA in fact is PBAP. Such a finding would however not affect the magnitude of the natural source contribution.

Tire debris is also a source of coarse mode contemporary carbon which we have not accounted for in our source apportionment. Tire treads have a natural rubber content of 0.5-3.5\% (Edeskär, 2004), thus we expect the contribution to be minor for the Scandinavian rural background environment. Emissions from cooking could make a significant contribution to contemporary carbon in urban areas, while we find this less likely for the rural background environment. The current study does not consider the increased use of biofuels in vehicle engines as we are trying to adapt to a carbon neutral society. Bennet et al. (2008) showed that the fraction modern $\left(\mathrm{F}^{14} \mathrm{C}\right)$ value in $\mathrm{PM}_{10}$ increased linearly with the percentage of biodiesel in the fuel. Consequently, any source apportionment attempting to separate biogenic from anthropogenic carbonaceous aerosol emissions involving ${ }^{14} \mathrm{C}$ will be affected.

Following an identical approach, i.e. using the same tracers as input to LHS statistical analysis as in the present study, Yttri et al. (2011) demonstrated that $\mathrm{OC}_{\mathrm{BSOA}}$ was successfully separated from other sources of contemporary carbon based on its seasonality, diurnal variation, and regional character.

\subsection{Biogenic oxidation products - pinic acid, organosulphates and nitrooxy organosulphates}

The highest mean concentration of biogenic oxidation products in aerosols was observed in Hyytiälä; e.g. the mean concentration of pinic acid was 2-3 times higher compared to the three other sites in the study. Hyytiälä is a continental site situated in the Boreal forest and thus likely experiences higher local and regional emissions of monoterpenes, as well as of isoprene compared to the other three sites. This is supported by the results obtained from the FLEXPART model which shows that the land surface categories involving trees (i.e. Broadleaved deciduous Trees; Mixed Forest; Needleleaf evergreen, Needleleaf deciduous; e.g. larch) was relatively more important for the Hyytiälä site $(69 \%)$ than for the three other sites $(40 \pm 3.5 \%)$ during the sampling period (see Fig. 3). Levels and temporal variation of biogenic oxidation products were comparable for Lille Valby and Vavihill, which is likely due to the relatively short distance $(<70 \mathrm{~km})$ between the two sites.

Organosulphates and nitrooxy organosulphates from isoprene and monoterpenes are formed through acid-catalyzed ring-opening of epoxides (Iinuma et al., 2009; Surratt et al., 2010) and through sulphate radical processes in the aerosol aqueous-phase (Nozière et al., 2010), while the previously suggested sulphate esterification mechanism (Liggio et al., 2005; Liggio and Li, 2006; Surratt et al., 2007) is not feasible at the $\mathrm{pH}$ of the atmospheric aerosol (Minerath et al., 2008). Formation of organosulphates and nitrooxy organosulphates thus occur during ageing of the aerosol and their concentrations depend on both the level of precursor compounds, as well as rate and conditions for the ageing processes. The concentration of first-generation biogenic oxidation products, such as pinic acid, is thus not necessarily correlated with levels of organosulphates and nitrooxy-organosulphates.

The concentration of the two nitrooxy organosulphates (denoted MW 295 and MW 297) measured (see Table 2) showed a noticeable dependency upon the land surface category mixed forest $\left(r^{2}=0.6-0.7\right)$, which did not account for more than $5-8 \%$ on average of the total terrestrial footprint during the sampling period. For the other land surface categories involving trees, i.e. Broadleaf deciduous $\left(r^{2}=0.4-0.5\right)$, Needleleaf evergreen and broadleaved deciduous trees $\left(r^{2}=0.3-0.4\right)$ the correlation was low or not existing. According to Surratt et al., 2008, limonene is the precursor of the nitroxy organosulphate MW 297, while MW 295 originates from oxidation of $\alpha$-pinene. In the European Boreal forest (Lindfors et al., 2000), as well as on the global scale (Griffin et al., 1999), emissions of $\alpha$-pinene is substantially higher than that of limonene, nevertheless, the concentrations of MW 297 is 1.4-1.8 times higher than that of MW 295, suggesting different formation pathways and/or reactions rates. Indeed, Kristensen and Glasius (2010) showed that concentrations of MW 297 peaked during night, suggesting involvement of the $\mathrm{NO}_{3}$ radical., whereas MW 295 peaked in the morning, thus pointing towards another formation pathway. Further, Andersson-Sköld and Simpson (2001) showed that with its higher yields, limonene can contribute more to the Nordic aerosol than species with higher emissions but lower yields, notably $\alpha$-pinene.

The concentration of MW 297 was 6-17 times higher during week one compared to the rest of the sampling period (i.e. week 2-4) at Birkenes, Lille Valby and Vavihill, whereas the relative contribution of MW 297 to $\mathrm{TC}_{\mathrm{p}}$ was increased by a factor of 4-5. The concentration of MW 295 was also increased during week one (by a factor of 3-5), but the relative contribution of MW 295 to $\mathrm{TC}_{\mathrm{p}}$ was less pronounced (increased by a factor 1.1-3.5) than seen for MW 297. These findings compare well with the increased Mixed forest footprint during week one, which was 
$11-15 \%$ compared to $3-4 \%$ for week $2-4$. The stagnant meteorological conditions observed during the first week of sampling at the three sites (see Sect. 3.1) probably provided favourable conditions for aging, explaining the increased levels of nitrooxy organosulphates observed, however, we find it difficult to explain the strong dependency on the mixed forest category and suggest that this might be a proxy for e.g. a defined geographical region, transport time.

\subsection{Estimating BSOA by BSOA tracers}

The contribution of each precursor to secondary organic carbon (SOC) could be determined by dividing the total tracer concentrations for each precursor in an ambient sample by the respective photochemical reaction chamber-derived SOC mass fraction given in Kleindienst et al. (2007; isoprene: $0.155 \pm 0.039, \alpha$-pinene: $0.231 \pm 0.111$, toluene: $0.0079 \pm 0.0026$, and $\beta$-caryophyllene: $0.023 \pm 0.0046$ ). The results indicate $\alpha$-pinene as the precursor with the largest contribution to measured levels of $\mathrm{TC}_{\mathrm{p}}$. The nine $\alpha$-pinene tracer compounds led to SOC contributions of $0.06 \mu \mathrm{g} \mathrm{C} \mathrm{m}^{-3}$. The three isoprene tracer compounds represent a SOC contribution of $0.01 \mu \mathrm{g} \mathrm{m}^{-3}$. Using the same procedure, the SOC contributions for toluene and $\beta$-caryophyllene were lower than $0.006 \mu \mathrm{g} \mathrm{m}^{-3}$, and $0.002 \mu \mathrm{g} \mathrm{m}^{-3}$, respectively. The sum of this estimate constitutes $8 \%$ of the $\mathrm{TC}_{\mathrm{p}}$ concentration, which is substantially less than the $50 \%$ mean contribution resulting from the Latin Hypercube Sampling approach (see Fig. 4). This observed deviation suggests there are BSOA precursor compounds which are not included in this estimation technique, and that those compounds may have significant contributions at the Birkenes location. Other BSOA formation pathways such as polymerization and ageing processes may also contribute to BSOA not accounted for by the tracer approach (El Haddad et al., 2011). On the other hand, the Tracer:SOA ratios used by Kleindienst et al. (2007) were extrapolated from experimental conditions very far from ambient conditions and were never claimed to be of general validity. In addition, the low ambient OC concentrations make our Nordic application of the technique even further removed from the experimental data than the ambient data analyzed by Kleindienst et al. (2007). Our conclusion from this pilot study is that factors used to convert BSOA tracers into SOC cannot be applied for the Nordic rural background environment without experimental verification and further insights into the chemical speciation of the ambient carbonaceous aerosol.

\section{Conclusions}

The combined effort of measuring organic tracers, thermaloptical- and $\mathrm{F}^{14} \mathrm{C}$-analyses, and Latin Hypercube Sampling in the present study has clearly demonstrated the abundance of carbonaceous aerosol originating from natural sources in the Nordic rural background environment in summer, accounting for $69-86 \%$ of $\mathrm{TC}_{\mathrm{p}}$. The biogenic secondary organic aerosol was the single most important source (48-57\%), followed by primary biological aerosol particles (20-32\%). The anthropogenic contribution was mainly attributed to fossil fuel sources (10-24\%), whereas no more than $3-7 \%$ was explained by combustion of biomass; i.e. emissions from residential wood burning and/or wild/agricultural fires. Fossil fuel sources totally dominated the ambient EC loading, accounting for $4-12 \%$ of $\mathrm{TC}_{\mathrm{p}}$, whereas $<1.5 \%$ was attributed to combustion of biomass.

The carbonaceous aerosol source apportionment showed only minor variation between the four selected sites. However, the Finnish site Hyytiälä and the Norwegian site Birkenes showed greater resemblance to each other, as did the Danish site Lille Valby and the Swedish site Vavihilll. Compared to Lille Valby and Vavihill, Hyytiälä and Birkenes had slightly higher contributions from natural sources; i.e. 82-86 \% for Birkenes and Hyytiälä and 69-74\% for Lille Valby and Vavihill. This difference was mainly attributed to PBAP, which had a relative contribution of $29-32 \%$ at Birkenes/Hyytiälä compared to $20 \%$ at Lille Valby/Vavihill. The presence of organosulphates and nitrooxy organosulphates in the Nordic rural background environment is demonstrated for the first time in the present study. The most abundant organosulphate compounds were an organosulphate of isoprene and nitrooxy-organosulphates of $\alpha$ - and $\beta$-pinene and limonene.

\section{Supplementary material related to this article is available online at: http://www.atmos-chem-phys.net/11/13339/2011/ acp-11-13339-2011-supplement.pdf.}

Acknowledgements. This work was supported by Nordic Council of Ministers, the Climate and Air Quality Group, the EU 6th framework EUCAARI (Contract 036833-2), the VILLUM FOUNDATION and UNECE (the EMEP project). Monitoring of EC/OC at Birkenes was supported by the Norwegian Climate and Pollution Agency, the EU 6th framework EUSAAR (Contract No. RII3-CT-2006-026140). The US Environmental Protection Agency through its Office of Research and Development collaborated in the research described here through Contract EP-D-05-065 to Alion Science and Technology. The manuscript has been subjected to internal peer review and has been cleared for publication.

Edited by: A. S. H. Prevot

\section{References}

Alves, C. A., Conçalves, C., Mirante, F., Nunes, T., Evtyugina, M., Sánchez de la Campa, A., Rocha, A. C., and Correia Marques, M.: Organic speciation of atmospheric particles in Alvão Natural Park (Portugal), Environ. Monit. Assess., 168, 321-337, doi:10.1007/s10661-009-1116-1, 2010. 
Andersson-Sköld, Y. and Simpson, D.: Secondary organic aerosol formation in Northern Europe: a model study, J. Geophys. Res., 106, 7357-7374, doi:10.1029/2000JD900656, 2001.

Atkinson, R. and Arey, J.: Gas-phase tropospheric chemistry of biogenic volatile organic compounds: a review, Atmos. Environ., 37, 197-219, 2003.

Bauer, H., Kasper-Giebl, A., Loflund, M., Giebl, H., Hitzenberger, R., Zibuschka, F., and Puxbaum, H.: The contribution of bacteria and fungal spores to the organic carbon content of cloud water, precipitation and aerosols, Atmos. Res., 64, 109-119, 2002.

Bauer, H., Claeys, M., Vermeylen, R., Schueller, E., Weinke, G., Berger, A., and Puxbaum, H.: Arabitol and mannitol as tracers for the quantification of airborne fungal spores, Atmos. Environ., 42, 588-593, 2008.

Bennett, M., Volckens, J., Stanglmaier, R., McNichol, A. P., Ellenson, W. D., and Lewis, C. W.: Biodiesel effects on particulate radiocarbon $\left({ }^{14} \mathrm{C}\right)$ emissions from a diesel engine, $\mathrm{J}$. Aerosol Sci., 39, 667-678, 2008.

Birch, M. E. and Cary, R. A.: Elemental carbon-based method for monitoring occupational exposures to particulate diesel exhaust, Aerosol Sci. Tech., 25, 221-241, 1996.

Carvalho, A., Pio, C., and Santos, C.: Water-soluble hydroxylated organic compounds in German and Finnish aerosols, Atmos. Environ., 37, 1775-1783, 2003.

Cavalli, F., Viana, M., Yttri, K. E., Genberg, J., and Putaud, J.-P.: Toward a standardised thermal-optical protocol for measuring atmospheric organic and elemental carbon: the EUSAAR protocol, Atmos. Meas. Tech., 3, 79-89, doi:10.5194/amt-3-79-2010, 2010.

Ceburnis, D., Garbaras, A., Szidat, S., Rinaldi, M., Fahrni, S., Perron, N., Wacker, L., Leinert, S., Remeikis, V., Facchini, M. C., Prevot, A. S. H., Jennings, S. G., Ramonet, M., and O'Dowd, C. D.: Quantification of the carbonaceous matter origin in submicron marine aerosol by ${ }^{13} \mathrm{C}$ and ${ }^{13} \mathrm{C}$ isotope analysis, Atmos. Chem. Phys., 11, 8593-8606, doi:10.5194/acp-11-8593-2011, 2011.

Chan, M. N., Surratt, J. D., Claeys, M., Edgerton, E. S., Tanner, R. L., Shaw, S. L., Zheng, M., Knipping, E. M., Eddingsaas, N. C., Wennberg, P. O., and Seinfeld, J. H.: Characterization and quantification of isoprene-derived epoxydiols in ambient aerosol in the Southeastern United States, Environ. Sci. Technol., 44, 4590-4596, doi:10.1021/es100596b, 2010.

Christoffersen, T. S., Hjorth, J., Horie, O., Jensen, N. R., Kotzias, D., Molander, L. L., Neeb, P., Ruppert, L., Winterhalter, R., Virkkula, A., Wirtz, K., and Larsen, B. R.: cis-pinic acid, a possible precursor for organic aerosol formation from ozonolysis of à-pinene, Atmos. Environ., 32, 1657-1661, 1998.

Donahue, N., Hartz, K., Chuong, B., Presto, A., Stanier, C., Rosenhørn, T., Robinson, A., and Pandis, S.: Critical factors determining the variation in SOA yields from terpene ozonolysis: a combined experimental and computational study, Faraday Discuss., 130, 295-309, doi:10.1039/b417369d, 2005.

Donahue, N. M., Robinson, A. L., and Pandis, S. N.: Atmospheric organic particulate matter: From smoke to secondary organic aerosol, Atmospheric Environment Fifty Years of Endeavour, Atmos. Environ., 43, 94-106, doi:10.1016/j.atmosenv.2008.09.055, 2009.

Dorman, J. L. and Sellers, P. J.: A Global climatology of albedo, roughness length and stomatal resistance for atmospheric general circulation models as represented by the simple biosphere model (SiB), J. Appl. Meteorol., 28, 833-855, 1989.

Dye, C. and Yttri, K. E.: Determination of monosaccharide anhydrides in atmospheric aerosols by use of high-resolution mass spectrometry combined with high performance liquid chromatography, Anal. Chem., 77, 1853-1858, 2005.

Edeskär, T.: Technical and environmental properties of tyre shreds focusing on ground engineering applications, Luleå Uni. Technol., Sweden, Tech. Rep., 2004:05, ISSN: 1402-1536, ISRN:TLU-TR-2004/5-SE, 2004.

El Haddad, I., Marchand, N., Temime-Roussel, B., Wortham, H., Piot, C., Besombes, J.-L., Baduel, C., Voisin, D., Armengaud, A., and Jaffrezo, J.-L.: Insights into the secondary fraction of the organic aerosol in a Mediterranean urban area: Marseille, Atmos. Chem. Phys., 11, 2059-2079, doi:10.5194/acp-11-20592011, 2011.

Gelencsér, A., May, B., Simpson, D., Sánchez-Ochoa, A., Kasper-Giebl, A., Puxbaum, H., Caseiro, A., Pio, C., and Legrand, M.: Source apportionment of $\mathrm{PM}_{2.5}$ organic aerosol over Europe: Primary/secondary, natural/anthropogenic, and fossil/biogenic origin, J. Geophys. Res., 112, D23S04, doi:10.1029/2006JD008094, 2007.

Genberg, J., Stenström, K., Elfman, M., and Olsson, M.: Development of Graphitization of $\mu \mathrm{g}$-Sized Samples at Lund University, Radiocarbon, 52, 1270-1276, 2010.

Glasius, M., Ketzel, M., Wahlin, P., Jensen, B., Monster, J., Berkowicz, R., and Palmgren, F.: Impact of wood combustion on particle levels in a residential area in Denmark, Atmos. Environ., 40, 7115-7124, doi:10.1016/j.atmosenv.2006.06.047, 2006.

Glasius, M., Ketzel, M., Wahlin, P., Bossi, R., Stubkjaer, J., Hertel, O., and Palmgren, F.: Characterization of particles from residential wood combustion and modelling of spatial variation in a low-strength emission area, Atmos. Environ., 42, 8686-8697, doi:10.1016/j.atmosenv.2008.04.037, 2008.

Gómez-González, Y., Surratt, J. D., Cuyckens, F., Szmigielski, R., Vermeylen, R., Jaoui, M., Lewandowski, M., Offenberg, J. H., Kleindienst, T. E., Edney, E. O., Blockhuys, F., Van Alsenoy, C., Maenhaut, W., and Claeys, M.: Characterization of organosulfates from the photooxidation of isoprene and unsaturated fatty acids in ambient aerosol using liquid chromatography/(-) electrospray ionization mass spectrometry, J. Mass. Spectrom., 43, 371-382, doi:10.1002/jms.1329, 2008.

Grieshop, A. P., Donahue, N. M., and Robinson, A. L.: Laboratory investigation of photochemical oxidation of organic aerosol from wood fires 2: analysis of aerosol mass spectrometer data, Atmos. Chem. Phys., 9, 2227-2240, doi:10.5194/acp-9-2227-2009, 2009a.

Grieshop, A. P., Logue, J. M., Donahue, N. M., and Robinson, A. L.: Laboratory investigation of photochemical oxidation of organic aerosol from wood fires 1: measurement and simulation of organic aerosol evolution, Atmos. Chem. Phys., 9, 1263-1277, doi:10.5194/acp-9-1263-2009, 2009b.

Hallquist, M., Wenger, J. C., Baltensperger, U., Rudich, Y., Simpson, D., Claeys, M., Dommen, J., Donahue, N. M., George, C., Goldstein, A. H., Hamilton, J. F., Herrmann, H., Hoffmann, T., Iinuma, Y., Jang, M., Jenkin, M. E., Jimenez, J. L., Kiendler-Scharr, A., Maenhaut, W., McFiggans, G., Mentel, Th. F., Monod, A., Prvt, A. S. H., Seinfeld, J. H., Surratt, J. D., Szmigielski, R., and Wildt, J.: The formation, 
properties and impact of secondary organic aerosol: current and emerging issues, Atmos. Chem. Phys., 9, 5155-5236, doi:10.5194/acp-9-5155-2009, 2009.

Hennigan, C. J., Sullivan, A. P., Collett, Jr., J. L., and Robinson, A. L.: Levoglucosan stability in biomass burning particles exposed to hydroxyl radicals, Geophys. Res. Lett., 37, L09806, 10.1029/2010g1043088, 2010.

Heringa, M. F., DeCarlo, P. F., Chirico, R., Tritscher, T., Dommen, J., Weingartner, E., Richter, R., Wehrle, G., Prévôt, A. S. H., and Baltensperger, U.: Investigations of primary and secondary particulate matter of different wood combustion appliances with a high-resolution time-of-flight aerosol mass spectrometer, Atmos. Chem. Phys., 11, 5945-5957, doi:10.5194/acp-11-5945-2011, 2011.

Hoffmann, T., Odum, J. R., Bowman, F., Collins, D., Klockow, D., Flagan, R. C., and Seinfeld, J. H.: Formation of organic aerosols from the oxidation of biogenic hydrocarbons, J. Atmos. Chem., 26, 189-222, 1997.

Hoffmann, D., Tilgner, A., Iinuma, Y., and Herrmann, H.: Atmospheric stability of levoglucosan: A detailed laboratory and modeling study, Environ. Sci. Technol., 44, 694-699, 2010.

Hoyle, C. R., Boy, M., Donahue, N. M., Fry, J. L., Glasius, M., Guenther, A., Hallar, A. G., Huff Hartz, K., Petters, M. D., Petj, T., Rosenoern, T., and Sullivan, A. P.: A review of the anthropogenic influence on biogenic secondary organic aerosol, Atmos. Chem. Phys., 11, 321-343, doi:10.5194/acp-11-321-2011, 2011.

Hu, D., Bian, Q., Li, T. W. Y., Lau, A. K. H. and Yu, J. Z.: Contributions of Isoprene, Monoterpenes, Beta-caryophyllene, and Toluene to Secondary Organic Aerosols in Hong Kong during the Summer of 2006, J. Geophys. Res., 113, D22206, doi:10.1029/2008JD010437, 2008.

Ion, A. C., Vermeylen, R., Kourtchev, I., Cafmeyer, J., Chi, X., Gelencsér, A., Maenhaut, W., and Claeys, M.: Polar organic compounds in rural $\mathrm{PM}_{2.5}$ aerosols from K-puszta, Hungary, during a 2003 summer field campaign: Sources and diel variations, Atmos. Chem. Phys., 5, 1805-1814, doi:10.5194/acp-5-1805-2005, 2005.

Iinuma, Y., Muller, C., Berndt, T., Boge, O., Claeys, M., and Herrmann, H.: Evidence for the existence of organosulfates from beta-pinene ozonolysis in ambient secondary organic aerosol, Environ. Sci. Technol., 41, 6678-6683, doi:10.1021/es070938t, 2007.

Iinuma, Y., Boge, O., Kahnt, A., and Herrmann, H.: Laboratory chamber studies on the formation of organosulfates from reactive uptake of monoterpene oxides, Phys. Chem. Chem. Phys., 11, 7985-7997, 2009.

Jaoui, M., Kleindienst, T. E., Lewandowski, M. and Edney, E. O.: Identification and Quantification of Aerosol Polar Oxygenated Compounds Bearing Carboxylic and/or Hydroxyl Groups Part 1: Method Development, Anal. Chem., 76, 4765-4778, 2004.

Jaoui, M., Kleindienst, T. E., Lewandowski, M., Offenberg, J. H., and Edney, E. O.: Identification and Quantification of Aerosol Polar Oxygenated Compounds Bearing Carboxylic or Hydroxyl Groups Part 2: Organic Tracer Compounds from Monoterpenes, Environ. Sci. Technol., 39, 5661-5673, 2005.

Jaoui, M., Corse, E., Kleindienst, T. E., Offenberg, J. H., Lewandowski, M., and Edney, E. O.: Analysis of Secondary organic aerosol compounds from the photooxidation of d-limonene in the presence of $\mathrm{NO}_{\mathrm{X}}$ and their detection in ambient $\mathrm{PM}_{2.5}$, Environ. Sci. Technol., 40, 3819-3828, 2006.

Kavouras, I. G. and Stephanou, E. G.: Direct evidence of atmospheric secondary organic aerosol formation in forest atmosphere through heteromolecular nucleation, Environ. Sci. Technol., 36, 5083-5091, 2002.

Kleindienst, T. E., Jaoui, M., Lewandowski, M., Offenberg, J. H., Lewis, C. W., Bhave, P. V., Edney, E. O.: Estimates of the contributions of biogenic and anthropogenic hydrocarbons to secondary organic aerosol at a Southeastern US location, Atmos. Environ., 41, 8288-8300, 2007

Kourtchev, I., Ruuskanen, T., Maenhaut, W., Kulmala, M., and Claeys, M.: Observation of 2-methyltetrols and related photo-oxidation products of isoprene in boreal forest aerosols from Hyytiälä, Finland, Atmos. Chem. Phys., 5, 2761-2770, doi:10.5194/acp-5-2761-2005, 2005.

Kourtchev, I., Ruuskanen, T. M., Keronen, P., Sogacheva, L., Dal Maso, M., Reissell, A., Chi, X., Vermeylen, R., Kulmala, M., Maenhaut, W., and Claeys, M.: Determination of isoprene and $\alpha$ - $/ \beta$-pinene oxidation products in boreal forest aerosols from Hyytiälä, Finland: diel variations and possible link with particle formation events, Plant. Biol., 10, 138-149, 2008a.

Kourtchev, I., Warnke, J., Maenhaut, W., Hoffmann, T., and Claeys, M.: Polar organic marker compounds in $\mathrm{PM}_{2.5}$ aerosol from a mixed forest site in western Germany, Chemosphere, 73, 13081314, 2008b.

Krecl, P., Ström, J., and Johansson, C.: Carbon content of atmospheric aerosols during the wood combustion season in Sweden, Atmos. Environ., 41, 6974-6985, 2007.

Kristensen, K. and Glasius, M.: Organosulfates and oxidation products from biogenic hydrocarbons in fine aerosols from a forest in North West Europe during spring, Atmos. Environ., 45, 4546-4556, 2011.

Kristensen, K., Glasius, M., Worton, D. R., Goldstein, A. H.: Nitrooxy-organosulfates in aerosol samples collected during the Biosphere Effects on Aerosols and Photochemistry Experiment (BEARPEX) in California, Poster presented at the International Aerosol Conference (IAC 2010), Helsinki, 29 August-3 September 2010.

Kunit, M. and Puxbaum, H.: Enzymatic determination of the cellulose content of atmospheric aerosols, Atmos. Environ., 30, 1233-1236, 1996.

Larsen, B. R., Di Bella, D., Glasius, M., Winterhalter, R., Jensen, N. R., and Hjorth, J.: Gas-phase OH oxidation of monoterpenes: Gaseous and particulate products, J. Atmos. Chem., 38, 231-276, 2001.

Lewandowski, M., Jaoui, M., Kleindienst, T. E., Offenberg, J. H., Edney, E. O., Sheesley, R. J. and Schauer, J. J.: Primary and Secondary Contributions to Ambient PM in the Midwestern United States, Environ. Sci. Technol. 42, 3303-3309, 2008.

Liggio, J. and Li, S.-M.: Organosulfate formation during the uptake of pinonaldehyde on acidic sulfate aerosols, Geophys. Res. Lett., 33, L13808, doi:10.1029/2006GL026079, 2006.

Liggio, J., Li, S.-M., and McLaren, R.: Reactive uptake of glyoxal by particulate matter, J. Geophys. Res., 110, D10304, doi:10.1029/2004JD005113, 2005.

Matthias-Maser, S. and Jaenicke, R.: Examination of atmospheric bioaerosol particles with radii $>0.2 \mu \mathrm{m}$, J. Aerosol Sci., 25, 1605-1613, 1994. 
May, B., Wagenbach, D., Hammer, S., Steier, P., Puxbaum, H., and Pio, C.: The anthropogenic influence on carbonaceous aerosol in the European background, Tellus B, 61, 464-472, 2009.

McDow, S. R. and Huntzicker, J. J.: Vapor adsorption artifact in the sampling of organic aerosol: face velocity effects, Atmos. Environ., 24, 2563-2571, 1990.

Minerath, E. C., Casale, M. T., and Elrod, M. J.: Kinetics feasibility study of alcohol sulfate esterification reactions in tropospheric aerosols, Environ. Sci. Technol., 42, 4410-4415, 2008.

Mitchell, K.: The Community. Noah Land-Surface Model (LSM). User's Guide. Public Release Version 2.7.1, available at: http://www.emc.ncep.noaa.gov/mmb/gcp/noahlsm/ Noah_LSM_USERGUIDE_2.7.1.htm (last access: 20 March 2011), 2005.

Nozière, B., Ekström, S., Alsberg, T., and Holmström, S.: Radical-initiated formation of organosulfates and surfactants in atmospheric aerosols, Geophys. Res. Lett., 37, L05806, doi:10.1029/2009g1041683, 2010.

Offenberg, J. H., Lewandowski, M., Edney, E. O., Kleindienst, T., and Jaoui, M.: Influence of aerosol acidity on the formation of secondary organic aerosol from biogenic precursor hydrocarbons, Environ. Sci. Technol., 43, 7742-7747, 2009.

Pöschl, U., Martin, S. T., Sinha, B., Chen, Q., Gunthe, S. S., Huffman, J. A., Borrmann, S., Farmer, D. K., Garland, R. M., Helas, G., Jimenes, J. L., King, S. M., Manzi, A., Mikhailov, E., Pauliquevis, T., Petters, M. D., Prenni, A. J., Roldin, P. Rose, D., Schneider, J., Su, H., Zorn, S. R., Artaxo, P., and Andreae, M. O.: Rainforest aerosols as biogenic, nuclei of clouds and precipitation in the Amazon, Science, 329, 1513-1516, 2010.

Puxbaum, H. and Tenze-Kunit, M.: Size distribution and seasonal variation of atmospheric cellulose, Atmos. Environ., 37, 36933699, 2003.

Puxbaum, H. Caseiro, A., Sánchez-Ochoa, A., Kasper-Giebl, A., Claeys, M., Gelencsér, A., Legrand, M., Preunkert, S., and Pio, C. A.: Levoglucosan levels at background sites in Europe for assessing the impact of biomass combustion on the European, aerosol background, J. Geophys. Res., 112, D23S05, doi:10.1029/2006JD008114, 2007.

Reimer, P. J., Brown, T. A., and Reimer, R. W.: Discussion: Reporting and calibration of post-bomb C-14 data, Radiocarbon, 46, 1299-1304, 2004.

Saarikoski, S., Timonen, H., Saarnio, K., Aurela, M., Järvi, L., Keronen, P., Kerminen, V.-M., and Hillamo, R.: Sources of organic carbon in fine particulate matter in northern European urban air, Atmos. Chem. Phys., 8, 6281-6295, doi:10.5194/acp-8-6281-2008, 2008.

Sanchez-Ochoa, A., Kasper-Giebl, A., Puxbaum, H., Gelencser, A., Legrand, M., and Pio, C.: Concentration of atmospheric cellulose: A proxy for plant debris across a west-east transect over Europe, J. Geophys. Res., 112, D23S08, doi:10.1029/2006JD008180, 2007.

Simoneit, B. R. T., Schauer, J. J., Nolte, C. G., Oros, D. R., Elias, V. O., Fraser, M. P., Rogge, W. F., and Cass., G. R.: Levoglucosan, a tracer for cellulose in biomass burning and atmospheric particles, Atmos. Environ., 33, 173-182, 1999.

Simpson, D., Yttri, K. E., Klimont, Z., Kupiainen, K., Caseiro, A., Gelencsér, A., Pio, C., and Legrand, M.: Modeling carbonaceous aerosol over Europe. Analysis of the CARBOSOL and EMEP EC/OC campaigns, J. Geophys. Res., 112, D23S14,
doi:10.1029/2006JD008114, 2007.

Skog, G.: The single stage AMS machine at Lund University: Status report, Nucl. Instrum. Meth. B, 259, 1-6, doi:10.1016/j.nimb.2007.01.190, 2007.

Skog, G., Rundgren, M., and Sköld, P.,: Status of the single sStage AMS machine at Lund University after 4 years of operation, Nucl. Instrum. Meth. B, 268, 895-897, doi:10.1016/j.nimb.2009.10.058, 2010.

Stocks, B. J., Mason, J. A., Todd, J. B., Bosch, E. M., Wotton, B. M., Amiro, B. D., Flannigan, M. D., Hirsch, K. G., Logan, K. A., Martell, D. L., and Skinner, W. R.: Large forest fires in Canada, 1959-1997, J. Geophys. Res., 107, 8149, doi:10.1029/2001JD000484, 2002.

Stohl, A., Forster, C., Frank, A., Seibert, P., and Wotawa, G.: Technical note: The Lagrangian particle dispersion model FLEXPART version 6.2, Atmos. Chem. Phys., 5, 2461-2474, doi:10.5194/acp-5-2461-2005, 2005.

Stohl, A., Berg, T., Burkhart, J. F., Fjae'raa, A. M., Forster, C., Herber, A., Hov, Ø., Lunder, C., McMillan, W. W., Oltmans, S., Shiobara, M., Simpson, D., Solberg, S., Stebel, K., Ström, J., Tørseth, K., Treffeisen, R., Virkkunen, K., and Yttri, K. E.: Arctic smoke - record high air pollution levels in the European Arctic due to agricultural fires in Eastern Europe in spring 2006, Atmos. Chem. Phys., 7, 511-534, doi:10.5194/acp-7-511-2007, 2007.

Surratt, J. D., Chan, A. W. H., Eddingsaas, N. C., Chan, M., Loza, C. L., Kwan, A. J., Hershey, S. P., Flagan, R. C., Wennberg, P. O., and Seinfeld, J. H.: Reactive intermediates revealed in secondary organic aerosol formation from isoprene, P. Natl. A. Sci. USA., 107, 6640-6645, 2010.

Surratt, J. D., Lewandowski, M., Offenberg, J. H., Jaoui, M., Kleindienst, T. E., Edney, E. O., and Seinfeld, J. H.: Effect of acidity on secondary organic aerosol formation from isoprene, Environ. Sci. Technol., 41, 5363-5369, 2007.

Szidat, S., Jenk, T. M., Gäggeler, H. W., Synal., H.-A., Fisseha, R., Baltensperger, U., Kalberer, M., Semburova, V., Wacker, L., Schwikowski, M., and Hajdas, I.: Source apportionment of aerosols by $\mathrm{C}-14$ measurements in different carbonaceous particle fractions, Radiocarbon 46, 475-484, 2004.

Szidat, S., Jenk, T. M., Synal., H.-A., Kalberer, M., Wacker, L., Hajdas, I., Kasper-Giebl, A., and Baltensperger, U.: Contributions of fossil fuel, biomass burning, and biogenic emissions to carbonaceous aerosols in Zürich as traced by $14 \mathrm{C}$, J. Geophys. Res., 111, 12 pp, doi:10.1029/2005JD006590, 2006.

Szidat, S., Ruff, M., Perron, N., Wacker, L., Synal., H.-A., Hallquist, M., Shannigrahi, A. S., Yttri, K. E., Dye, C., and Simpson, D.: Fossil and non-fossil sources of organic carbon (OC) and elemental carbon (EC) in Göteborg, Sweden, Atmos. Chem. Phys., 9, 1521-1535, doi:10.5194/acp-9-1521-2009, 2009.

Tunved, P., Hansson, H.-C., Kerminen, V.-M., Ström, J., Dal Maso, M., Lihavainen, H., Viisanen, Y., Aalto, P. P., Komppula, M., and Kulmala., M.: High natural aerosol loading over boreal forests, Science, 261-263, 2006.

Turpin, B. J., Huntzicker, J. J., and Hering S. V.: Investigation of organic aerosol sampling artefacts in the Los Angeles basin, Atmos. Environ., 28, 3061-3071, 1994.

Winiwarter, W., Haberl, H., and Simpson, D.: On the boundary between man-made and natural emissions: Problems in defining 
European ecosystems, J. Geophys. Res., 104, 8153-8159, 1999.

Yttri, K.E., Dye, C., Slørdal., L.H., and Braathen, O.-A.: Quantification of monosaccharide anhydrides by liquid chromatography combined with mass spectrometry: Application to aerosol samples from an urban and a suburban site influenced by small-scale wood burning, J. Air Waste Manag. Assoc., 55, 1169-1177, 2005.

Yttri, K. E., Aas, W., Bjerke, A., Cape, J. N., Cavalli, F., Ceburnis, D., Dye, C., Emblico, L., Facchini, M. C., Forster, C., Hanssen, J. E., Hansson, H. C., Jennings, S. G., Maenhaut, W., Putaud, J. P., and Tørseth, K.: Elemental and organic carbon in $\mathrm{PM}_{10}$ : a one year measurement campaign within the European Monitoring and Evaluation Programme EMEP, Atmos. Chem. Phys., 7, 5711-5725, doi:10.5194/acp-7-5711-2007, 2007.
Yttri, K. E., Dye, C., and Kiss, G.: Ambient aerosol concentrations of sugars and sugar-alcohols at four different sites in Norway, Atmos. Chem. Phys., 7, 4267-4279, doi:10.5194/acp-7-4267-2007, 2007.

Yttri, K. E., Simpson, D., Stenström, K., Puxbaum, H., and Svendby, T.: Source apportionment of the carbonaceous aerosol in Norway quantitative estimates based on 14C, thermal-optical and organic tracer analysis, Atmos. Chem. Phys., 11, 9375-9394, doi:10.5194/acp-11-9375-2011, 2011.

Yu, J., Cocker III, D. R., Griffin, R. J., Flagan, R. C., and Seinfeld, J. H.: Gas-phase ozone oxidation products of monoterpenes: gaseous and particulate products, J. Atmos. Chem., 34, 207-258, 1999. 